\title{
Serotonin-Storing Secretory Granules from Thyroid Parafollicular Cells
}

\author{
J. M. Barasch, H. Tamir,' E. A. Nunez, and M. D. Gershon \\ Department of Anatomy and Cell Biology, Columbia University College of Physicians and Surgeons, and 'Division of \\ Neuroscience, New York State Psychiatric Institute, New York, New York, 10032
}

\begin{abstract}
The subcellular storage of 5-HT was studied in sheep thyroid parafollicular cells. These cells are neural crest derivatives and were investigated as a serotonergic model system. Light and electron microscopic immunocytochemistry was used to examine the distributions of $5-\mathrm{HT}, 45$ and $56 \mathrm{kDa}$ forms of 5-HT binding protein (SBP), and calcitonin. A single type of parafollicular cell was found that contained calcitonin, 5-HT, and 45 kDa SBP but not 56 kDa SBP. The secretory granules of parafollicular cells all displayed calcitonin immunoreactivity, and many were also immunoreactive for 5-HT and 45 kDa SBP. Granules were isolated, first by size and then by density, on successive metrizamide gradients. These provided a granular fraction that was enriched in calcitonin, endogenous 5-HT, and $45 \mathrm{kDa}$ SBP. Immunoblots confirmed the presence of $45 \mathrm{kDa}$ SBP in the isolated granules and in suspensions of parafollicular cells that were purified by an affinity chromatographic technique. Parafollicular cell granules did not appear to contain substantial stores of ATP. Granules isolated on Percoll gradients were morphologically homogeneous and took up ${ }^{3} \mathrm{H}-5-\mathrm{HT}$. The specificity of this uptake was confirmed by quantitative electron microscopic radioautography. The granular uptake of ${ }^{3} \mathrm{H}-5-\mathrm{HT}$ was inhibited by reserpine $(10 \mu \mathrm{M})$. It is concluded that parafollicular cell granules are different from other amine-storing vesicles that do contain ATP; nevertheless, since parafollicular cell granules store 5-HT and have the same $45 \mathrm{kDa}$ SBP as is found in serotonergic axon terminals, parafollicular cell granules may be analogous to the synaptic vesicles of serotonergic neurons.
\end{abstract}

A great deal has recently been learned about the subcellular storage and release of catecholamines (Johnson and Scarpa, 1979; Thureson-Klein, 1983; Holz, 1986). Whether this information can be generally applied to the storage of other neurotransmitters, such as 5-HT, has not yet been established. In order to determine how alike subcellular storage organelles for 5-HT and catecholamines are, it is necessary to isolate and study vesicles that contain 5-HT. Synaptic vesicles, specialized for the storage of 5-HT, have been difficult to isolate. Serotonergic neurons in both brain and gut exist in mixed populations with other types

\footnotetext{
Received Feb. 24, 1987; revised June 3, 1987; accepted June 5, 1987.

This work was supported by Grants NS 12969, NS 07062, and AM19547 from the NIH and NIMH 37575

Correspondence should be addressed to Dr. Michael D. Gershon, Department of Anatomy and Cell Biology, Columbia University College of Physicians and Surgeons, 630 West 168th Street, New York, NY 10032.

Copyright (c) 1987 Society for Neuroscience $0270-6474 / 87 / 124017-17 \$ 02.00 / 0$
}

of neuron (Dahlstrom and Fuxe, 1964; Fuxe and Jonsson, 1967; Gershon, 1977, 1981). Consequently, it has not yet proved to be possible to separate serotonergic neurons or serotonergic synaptic vesicles from neurons or synaptic vesicles containing other neurotransmitters (Slotkin et al., 1978). Moreover, the synaptic vesicles of serotonergic neurons appear to be quite fragile and, as a result, tend to be destroyed by procedures that liberate synaptic vesicles from isolated synaptosomes (DeLorenzo and Freedman, 1978; Tamir and Gershon, 1979). Similar difficulties have been overcome for studies of catecholamine storage by using the chromaffin cells of the adrenal medulla as a model system; thus, much of what is known about neurectodermal catccholaminc storagc has becn lcarncd from investigations of adrenal medullary chromaffin granules (Winkler, 1976; Johnson and Scarpa, 1979; Winkler and Westhead, 1980; Phillips, 1982). In an analogous manner, to study the properties of the neuronaltype of 5-HT subcellular storage organelle, we have analyzed the secretory vesicles of thyroid parafollicular cells, seeking to use the vesicles of these cells as a model for what may be a generally applicable neurectodermal type of 5-HT storage.

The thyroid gland has 2 different kinds of parenchymal cell. One, the follicular cell, is an endodermal derivative that is responsible for secretion of thyroxine and triiodothyronine (Ingbar, 1985). The other, the parafollicular cell, is a neural crest derivative (Polak et al., 1974; Le Douarin, 1982) and is responsible for secreting calcitonin (Pearse, 1966; Bussolati and Pearse, 1967; Kalina and Pearse, 1971) and, at least in species such as sheep, goat, horse, bat, and callithricid primate, 5-HT as well (Falck and Owman, 1968; Jaim-Etcheverry and Zeiher, 1968; Gershon and Nunez, 1970; Nunez and Gershon, 1972; Machado, 1976). Although no presynaptic input to parafollicular cells has been identified, and the cells lack axons, they share several characteristics with neurons and have been called paraneurons (Fujita, 1977; Fujita et al., 1984). Moreover, parafollicular cells express some neural characteristics when cultured and exposed to NGF (Barasch ct al., 1987). Under thesc conditions, the cells extend neurites and express the neural product of the calcitonin gene, calcitonin gene-related peptide (in situ, sheep parafollicular cells contain calcitonin, but calcitonin gene-related peptide is not detectable). Sheep parafollicular cells also resemble serotonergic neurons in that they contain the enzymes, tryptophan hydroxylase and aromatic L-amino decarboxylase, and thus are capable of the biosynthesis of 5-HT from L-tryptophan (Nunez and Gershon, 1972). In this respect, parafollicular cells differ from platelets (Garattini and Valzelli, 1965) and adrenal chromaffin cells, which contain 5-HT but cannot synthesize it from L-tryptophan (Verhofstad and Jonsson, 1983; Holzwarth and Sawetawan, 1985). Furthermore, correlative evi- 
dence suggests that sheep parafollicular cells may contain the neurectodermal type of 5-HT binding protein (SBP) (Bernd et al., 1979, 1981). This protein is also found in synaptic vesicles of the serotonergic neurons of brain (Tamir et al., 1976; Tamir and Gershon, 1979; Liu et al., 1985) and gut (Jonakait et al., 1977, 1979; Gershon et al., 1983) but is not found in cells that are derived from germ layers other than neurectoderm, even if these other cells, such as enterochromaffin cells, mast cells, and platelets, store 5-HT (Tamir et al., 1980; Gershon and Tamir, 1984).

Although prior work has confirmed the presence of both 5-HT and calcitonin in sheep parafollicular cells (Atack et al., 1972), the possibility that there may be subsets of parafollicular cells that contain only one or the other of these substances has not been ruled out. The costorage of 5 - HT and calcitonin in the same secretory vesicle is suggested by the release of both substances from cells in response to the stimulus of elevating the ambient concentration of $\mathrm{Ca}^{+2}$ (Gershon et al., 1978). Furthermore, all newly synthesized parafollicular cell 5 -HT has been localized to the storage vesicles (Nunez and Gershon, 1972). Again, no subsets of parafollicular storage vesicles have been identified (Jaim-Etcheverry and Zeiher, 1968; Ericson, 1970; Atack et al., 1972; Zabel, 1983, 1984); nevertheless, the possibility that some vesicles contain calcitonin while others contain 5-HT has not been eliminated.

In the current study, we have attempted to isolate and begin the characterization of thyroid parafollicular 5-HT storage vesicles. We also sought to determine if there are subsets of parafollicular cells or their subcellular vesicles that are differentially specialized for the storage of 5-HT or calcitonin. The possible colocalization of SBP with 5-HT and/or calcitonin was investigated. The idea that the SBP of the thyroid and that of neurons are the same or similar molecules was analyzed immunologically. Finally, we tested the hypothesis that parafollicular 5-HT storage vesicles are similar to adrenal medullary chromaffin granules by studying the association of ATP with the parafollicular vesicles. Adrenal medullary chromaffin granules are so rich in ATP that ATP can be used as a marker for these granules in isolated subcellular fractions (Carty et al., 1980).

\section{Materials and Methods}

Isolation of parafollicular cell granules. Fresh lamb thyroid glands were obtained from a nearby slaughter house, packed in ice, and were brought within $90 \mathrm{~min}$ to the laboratory. The glands were cleaned of connective tissue, minced finely in the presence of collagenase $(1 \%, 325 \mathrm{U} / \mathrm{mg}$, Worthington Biochemical Corp., New Brunswick, NJ), and subjected to gentle homogenization in a solution of $0.33 \mathrm{~m}$ sucrose (SchwartzMann), containing the monoamine oxidase inhibitors, pargyline $(0.1$ $\mathrm{mm}$, Sigma Chem. Co., St. Louis), and clorgyline (10.0 $\mu \mathrm{M}$, May and Baker, London, U.K.). The homogenate was centrifuged at low speed $(1200 \times g, 5 \mathrm{~min})$ to provide a pellet of unbroken cells, nuclei, and connective tissues. This pellet was rehomogenized as above, centrifuged again, and the resulting supernatant was combined with that of the first homogenate. The combined supernatants were recentrifuged, a pellet was again removed, and the supernatant was subjected to centrifugation at $9700 \times \mathrm{g}$ for $20 \mathrm{~min}$. The resultant "crude granular pellet" was washed once.

The procedure to isolate parafollicular cell granules from the "crude granular pellet" separated particles first according to size and then according to density. Eight milligrams of protein from the crude granular pellet, resuspended in $6 \mathrm{ml}$ of $0.33 \mathrm{~m}$ sucrose, was layered over a 3-step discontinuous metrizamide gradient, consisting of $5 \mathrm{ml}$ of $12 \%, 5 \mathrm{ml}$ of $16 \%$, and $15 \mathrm{ml}$ of $20 \%$ metrizamide (Sigma) in $0.33 \mathrm{~m}$ sucrose. The gradient was centrifuged in a Beckman SW 27 swinging bucket rotor at $13,200 \times g$ for $44 \mathrm{~min}$. Five fractions were recovered from the gradients by aspiration with hooked glass pipettes.
Each fraction was assayed for its content of parafollicular cell granules (see below). The layer of this "primary gradient" found to contain the highest concentration of parafollicular cell granules was subsequently applied to a second metrizamide gradient and centrifuged until the granules equilibrated at their buoyant density. Four or $5 \mathrm{ml}$ of granulecontaining "primary gradient" were layered over a 3-step discontinuous metrizamide gradient consisting of $2.5 \mathrm{ml}$ of $18 \%, 2.5 \mathrm{ml}$ of $28 \%$ and $2.5 \mathrm{ml}$ of $38 \%$ metrizamide in $0.33 \mathrm{M}$ sucrose. This "secondary gradient" was centrifuged at $110,000 \times g$ for $2 \mathrm{hr}$ in a Beckman SW 41 swinging bucket rotor. Four fractions were collected from the interfaces, and assayed for the presence of parafollicular cell granules and contaminating subcellular components.

A number of other gradients were analyzed for their capacity to fractionate the crude granular pellet. These included continuous linear and discontinuous sucrose gradients and a continuous linear gradient of Percoll (Pharmacia; Piscataway, NJ). A 50\% continuous linear Percoll gradient was made isotonic with $140 \mathrm{mM} \mathrm{KCl}, 5 \mathrm{~mm} \mathrm{NaCl}$, and $20 \mathrm{~mm}$ potassium phosphate buffer $(\mathrm{pH} 7.4)$ with $0.1 \mathrm{~mm}$ pargyline added. The addition of these salts, to more closely approximate intracellular conditions, has been found to facilitate the isolation of amine-containing synaptic vesicles (DeLorenzo and Freedman, 1978; Tamir and Gershon, 1979). The crude granular pellet $(2.5 \mathrm{ml})$, resuspended in $0.33 \mathrm{M}$ sucrose, was mixed with $30 \mathrm{ml}$ of $50 \%$ isotonic Percoll-salt solution and centrifuged at $9700 \times \mathrm{g}$ for $1 \mathrm{hr}$ (Sorvall SS-34 rotor). A continuous linear Percoll gradient formed during centrifugation. This gradient was collected in 5 fractions, which were assayed for their content of parafollicular granules and other subcellular components.

Assay of 5-HT. Aliquots of gradient fractions were acidified to $0.1 \mathrm{~N}$ $\mathrm{HCl}$ and centrifuged for one hour at $100,000 \times g$. Aliquots of the clear supernatant were subjected to reverse-phase, high-pressure liquid chromatography (HPLC) with electrochemical detection (Reinhard et al., 1980). The HPLC system consisted of a Waters (Waterbury, CT) L550 pump, a Waters $\mu$ Bondapak C-18 column $(3.9 \times 300 \mathrm{~mm}, 10 \mu \mathrm{m}$ particle size), a $30 \mu \mathrm{m}$ particle guard column, and a Bioanalytical Systems (West Lafayette, IN.) LC-4A amperometric detector coupled to a TL-5 glassy carbon electrode. Indolamine concentrations in gradient fractions were estimated by measuring the areas under peaks in the record of the output of the electrochemical detector. Areas were measured by computer-assisted planimetry (Bioquant II-K\&M Inst. Co., Nashville, TN).

Electron microscopy. The crudc granular pcllct and gradicnt fractions were fixed overnight at $4^{\circ} \mathrm{C}$ with $4 \%$ glutaraldehyde in $0.1 \mathrm{~m}$ sodium phosphate buffer ( $\mathrm{pH}$ 7.4). Fractions were then pelleted, washed with that buffer $(1 \mathrm{hr})$, and postfixed with $1 \% \mathrm{OsO}_{4}(1 \mathrm{hr})$. The osmicated fractions were centrifuged in nitrocellulose tubes at high speed to form a firm pellet, which was then washed, dehydrated with a graded series of ethanols, and embedded in an epoxy resin (Epon 812). Thin sections were stained with uranyl acetate and lead citrate and examined with a JEOL JEM $100 \mathrm{C}$ electron microscope. The proportional volume occupied by parafollicular cell granules in the crude granular pellet and in gradient fractions isolated on metrizamide and Percoll gradients was analyzed by point count planimetry (Elias et al., 1971).

Electron microscopic radioautography of ${ }^{3} \mathrm{H}-5-\mathrm{HT}$. Ten milligrams of crude granular pellet were incubated with $6 \mu \mathrm{M}{ }^{3} \mathrm{H}-5-\mathrm{HT}(13 \mathrm{Ci} /$ mmol, Amersham Corp.) in $30 \mathrm{~mm}$ Tris maleate buffer (pH 7.4) and $0.27 \mathrm{M}$ sucrose at $37^{\circ} \mathrm{C}$ for $10 \mathrm{~min}$. Free ${ }^{3} \mathrm{H}-5-\mathrm{HT}$ was then removed by pelleting and washing the subcellular components in $0.33 \mathrm{~m}$ sucrose. The washed radioactive fraction was applied to a continuous linear Percoll gradient. Fractions recovered from this gradient were fixed in $4 \%$ glutaraldehyde made hypertonic with $3 \%$ sucrose (Gershon and Ross, $1966 \mathrm{a}$, b), postfixed with $1 \% \mathrm{OsO}_{4}$ (containing $3 \%$ sucrose), and embedded in Epon 812. Thin sections were cut and subjected to electron microscopic radioautography, using Ilford L4 emulsion, as previously described (Goodrich et al., 1980). Grain distribution in electron microscopic radioautographs was analyzed by the method of Williams (1969).

Enzymatic assay of ATP. Metrizamide gradient fractions were acidified immediately upon isolation to $\mathrm{pH} 4.5$ with $20 \mathrm{~mm}$ sodium acetate and frozen at $-70^{\circ} \mathrm{C}$ overnight. ATP was assayed using the firefly luciferin-luciferase system (Rasmussen and Nielsen, 1968) on a Dupont Biometer(Wilmington, DE). An incubation medium that contained 0.01 M morpholino propane sulfonic acid buffer ( $\mathrm{pH} 7.4), 0.01 \mathrm{M} \mathrm{MgSO}_{4}$, $0.71 \mathrm{~mm}$ luciferin, and 100 units of luciferase was used. The reaction was started by rapidly mixing $0.5 \mathrm{ml}$ of incubation media with $10 \mu \mathrm{l}$ of sample. The peak luminescence was compared with that of a known standard of ATP. Potential inhibition of the luciferin-luciferase rection 
by metrizamide in the samples was ruled out by comparing luminescence of ATP standards in the presence and absence of concentrations of metrizamide equal to those used in the gradients.

Cytochemical demonstration of ATP. The uranaffin reaction (Richards and Da Prada, 1977) was used to visualize intracellular concentrations of ATP. Freshly obtained sheep thyroids and mouse adrenal glands were fixed with glutaraldehyde, as above, incubated with $4 \%$ uranyl acetate (pH 3.9) overnight, and embedded in Epon 812. Parafollicular and chromaffin cells were then examined ultrastructurally.

Immunocytochemical localization of calcitonin, 5-HT, somatostatin, and $S B P$. Fresh lamb thyroids were fixed by a modification of the 2-step procedure of Berod et al. (1981). The tissues were initially submerged in a mixture of $4 \%$ formaldehyde (from paraformaldehyde) and $0.05 \%$ glutaraldehyde with $3.0 \%$ sucrose in $0.1 \mathrm{~m}$ phosphate buffer $(\mathrm{pH}$ 7.4) for $20 \mathrm{~min}$. The blocks were then transferred to a solution of $4 \%$ formaldehyde (from paraformaldehyde) with $3.0 \%$ sucrose in $0.1 \mathrm{~m}$ borate buffer ( $\mathrm{pH}$ 9.5) and fixation was continued for $4 \mathrm{hr}$. Fixed tissues were then cryoprotected by infiltration with $30 \%$ sucrose in $0.1 \mathrm{M}$ phosphate buffer overnight, embedded in OCT (Miles Scientific, Naperville, IL), and frozen with liquid nitrogen. Sections $(6-12 \mu \mathrm{m})$ were cut at $-20^{\circ} \mathrm{C}$ using a cryostat-microtome. The sections were mounted on albumin-coated slides and incubated with one of 3 pairs of primary antisera. These primary antisera were raised in different species so that 2 substances could be located simultaneously using appropriate speciesspecific secondary antibodies (Barasch et al., 1987). A rat monoclonal antibody to 5-HT (1:200 or 1:400; Seralabs, Westbury, NY) was combined with a rabbit antiserum to human calcitonin (1:200 or 1:400; Immunonuclear Corp, Stillwater, $\mathrm{MN}$ ), or a rabbit antiserum to somatostatin (1:100; Immunonuclear). The primary antibodies were localized using tetramethylrhodamine isothiocyanate (TRITC) coupled to goat anti-rat IgG (Kirkegaard and Perry, Gaithersburg, MD) and with fluorescein isothiocyanate (FITC) coupled to goat anti-rabbit IgG (MilesYeda, Rehovot, Israel). Controls, not exposed to the primary antisera, showed no staining. Immunostaining due to 5-HT was blocked by incubation with the 5-HT-albumin conjugate used to raise antibodies to 5-HT. SBP immunoreactivity was localized with partially purified rabbit antiserum to rat $45 \mathrm{kDa}$ SBP and with affinity-purified antiserum to rat $56 \mathrm{kDa}$ SBP. The anti-45 kDa SBP and anti-56 kDa SBP sera were raised by immunizing rabbits with mild tryptic digests of the highly purified proteins (Liu et al., 1985; Tamir et al., 1986). Each serum yielded only a single immunoreactive band when examined by immunoblot analysis against a crude protein preparation obtained by $\left(\mathrm{NH}_{4}\right)_{2} \mathrm{SO}_{4}$ fractionation (0-30\%) of the $100,000 \times \mathrm{g}$ supernatant of centrifuged rat brain homogenate. No horse serum was utilized to study the immunoreactivity of $56 \mathrm{kDa}$ SBP and $5 \%$ nonfat dry milk in $0.1 \mathrm{M}$ PBS ( $\mathrm{pH} 7.4$ ) with $0.05 \%$ Tween 20 was substituted for horse serum for the demonstration of $45 \mathrm{kDa}$ SBP. Immunoreactivity was visualized with TRITC coupled to goat anti-rabbit IgG. Controls for SBP immunolocalization included preimmunc sera, as well as washes from the affinity column used to purify antisera to $56 \mathrm{kDa}$ SBP. Although antibody to $45 \mathrm{kDa}$ SBP could not be eluted from an affinity column, passage of sera through the column removed all anti-45 kDa SBP immunoreactivity. Sections in which SBP immunoreactivity had been localized were reincubated with anti-5-HT serum to investigate the possible colocalization of 5-HT and SBP. 5-HT immunoreactivity was visualized with FITC coupled to goat anti-rat IgG.

Stained cryostat sections were mounted with $80 \%$ glycerol in $0.1 \mathrm{M}$ PBS and examined and photographed with a Leitz Ortholux microscope equipped for vertical fluorescence microscopy (Ploem). Fluorescence of FITC was selectively visualized using the " $\mathrm{L}_{2}$ " filter cube and TRITC with the " $\mathrm{N}_{2}$ " filter cube. These permitted the visualization of each fluorophore individually with no interference of one with the other.

Electron microscopic immunocytochemical localization of calcitonin, 5-HT, and $45 \mathrm{kDa} S B P$. Fresh lamb thyroids, crude granular pellet, and purified parafollicular cell granules that were isolated on metrizamide gradients were fixed in a mixture of $4 \%$ formaldehyde (from paraformaldehyde), $0.1 \%$ glutaraldehyde in $0.1 \mathrm{~m}$ sodium phosphate buffer ( $\mathrm{pH}$ 7.4) with $3 \%$ sucrose for $3 \mathrm{hr}$ at $4^{\circ} \mathrm{C}$. Fixed tissues and pellets were washed overnight and residual aldehyde groups were quenched by treating the specimens first with $0.1 \mathrm{M}$ sodium periodate in $0.1 \mathrm{M}$ phosphate buffer $(10 \mathrm{~min})$ and then with $0.1 \%$ sodium borohydride in $0.1 \mathrm{M}$ phosphate buffer $(10 \mathrm{~min})$. Tissues and pellets were then washed, dehydrated, and embedded in LR White (a hydrophilic embedding agent; Ernest Fullam, Schenectady, NY) for immunocytochemistry (Payette et al., 1986). Thin sections were picked up on Formvar-coated nickel grids, treated with $10 \%$ horse serum in Tris-buffered saline containing $0.125 \%$ Triton-X 100 , and stained overnight at $4^{\circ} \mathrm{C}$ with rabbit antiserum to human calcitonin (diluted 1:200 with $4 \%$ horse serum in TBS containing $0.125 \%$ Triton-X 100). Grids were subsequently washed and incubated for $3 \mathrm{hr}$ at room temperature with a goat anti-rabbit secondary antibody coupled to $20 \mathrm{~nm}$ particles of colloidal gold (diluted 1:20 with $4 \%$ horse serum and $0.125 \%$ Triton-X 100 in TBS; Janssen Pharmaceutical Co., Bearse, Belgium). The treated grids were washed, postfixed with $2.5 \%$ glutaraldehyde in $0.1 \mathrm{M}$ phosphate buffer for $10 \mathrm{~min}$, stained with uranyl acetate and lead citrate, and examined by electron microscopy. The possible subcellular costorage of 5-HT with calcitonin or with $45 \mathrm{kDa}$ SBP was investigated similarly, except that tissues were fixed by the method of Berod et al. (1981). This procedure was required in order to minimize exposure to glutaraldehyde and thus preserve the immunogenicity of 5-HT. A rat monoclonal antibody was used for the localization 5-HT and rabbit polyclonal antisera (see above) were used to demonstrate calcitonin or $45 \mathrm{KDa}$ SBP. In a few experiments, a guinea pig polyclonal antiserum to 5-HT (Arnel Products Co., Brooklyn, NY) was also evaluated. Species-specific secondary antibodies coupled to $5 \mathrm{~nm}$ (5-HT; goat anti-rat or goat anti-guinea pig, diluted 1:20), $20 \mathrm{~nm}$ (calcitonin; goat anti-rabbit diluted 1:20), or $15 \mathrm{~nm}(45 \mathrm{kDa}$ SBP; goat antirabbit diluted $1: 20$ ) particles of colloidal gold permitted the simultaneous visualization of 5-HT in combination with either of the other 2 antigens. Because of the possible interaction of 5-HT and $45 \mathrm{kDa}$ SBP binding sites, the subcellular localization of the $45 \mathrm{kDa} 5-\mathrm{HT}$ binding protein was also investigated quantitatively in singly labeled material. Sections were incubated with the primary antibody, as described above, and sites of immunoreactivity were located with a goat anti-rabbit IgG secondary antibody coupled to $5 \mathrm{~nm}$ particles of colloidal gold. The number of gold particles lying over subcellular constituents was determined. The proportional volume occupied by these same constituents was then ascertained by point-count planimetry (Elias et al., 1971). This volume was used to compute the expected numbers of gold particles that would be found over subcellular components if gold particles were distributed randomly. The actual and expected distributions of gold particles were statistically compared by $\chi^{2}$ analysis.

Assay of SBP. Whole thyroid homogenate, crude granular pellets, and parafollicular cell granules partially purified on primary metrizamide gradients, were analyzed for SBP activity. Each sample was adjusted to pH 7.4 with $20 \mathrm{~mm} \mathrm{KPO}_{4}$ buffer and frozen in the presence of the proteolytic enzyme inhibitors, ethylene diaminotetraacetic acid (EDTA; $1 \mathrm{mM})$, ethyleneglycol-bis-( $\beta$-amino-ethyl ether)- $N, N^{\prime}$-tetraacetic acid (EGTA; $1 \mathrm{mM}$ ), and phenylmethylsulphonyl fluoride (PMSF; $1.5 \mathrm{~mm}$ ). Prior to freezing, primary gradient vesicles were diluted $1: 3$ with 0.33 M sucrose and pelleted $(9700 \times \mathrm{g}, 20 \mathrm{~min})$ in order to remove most of the metrizamide. After thawing, the tissues were subjected to vigorous homogenization and centrifuged $(100,000 \times g$, for $1 \mathrm{hr})$. A clear supernatant was obtained. It was decanted, and soluble proteins were precipitated by $0-30 \%, 30-60 \%$, or $0-60 \%$ ammonium sulfate fractionation. Precipitated proteins were collected by brief centrifugation $(27,000 \times$ $g$, for $15 \mathrm{~min}$ ), and the resulting pellet was resuspended in $20 \mathrm{mM} \mathrm{KPO}_{4}$ buffer containing $10 \%$ glycerol. Proteins were desalted on Sephadex G-50 columns $(1 \times 10 \mathrm{~cm})$ and immediately assayed for 5-HT binding activity (Tamir et al., 1976).

Isolation of parafollicular cells. Parafollicular cells were separated from follicular cells by a chromatographic method that has previously been described (Bernd et al., 1981). Essentially, trypsin-dissociated thyroid cells in Eagle's minimum essential medium (MEM; $+1 \%$ BSA) were activated by incubation with thyroid stimulating hormone (TSH). TSH causes follicular cells to extend phagocytic pseudopods, which in vivo are active in the endocytosis of thyroglobulin (Fujita, 1975). The activated cell suspension was then passed over a column of Sepharose$6 \mathrm{MB}$ coupled to thyroglobulin. Follicular cells are retained on the column, while parafollicular cells, erythrocytes, and other contaminants pass through. The column effluent was then loaded onto a cushion of $10 \%$ Ficoll in MEM and centrifuged briefly ( $200 \times \mathrm{g}$ for $10 \mathrm{~min})$. The erythrocytes and other contaminants were decanted from the top of the gradient and the parafollicular cells were collected in a loose pellet. About $97 \%$ of the thyroid cells in the final pellet are parafollicular.

Other assays. Protein was assayed by the fluorescamine method of Udenfriend et al. (1972). $\beta$-Glucuronidase was measured spectrophotometrically as described by Fishman et al. (1948). Succinic dehydrogenase was measured by the 2,6-dichlorophenolindophenol-phenazine methosulfate system described by Cerletti et al. (1967). The reaction volume for this indophenol reduction assay was $1 \mathrm{ml}$, and samples were 
Figure 1. Simultaneous localization of calcitonin $(A)$ and 5-HT $(B)$ immunoreactivities in a follicle of the sheet thyroid gland. Primary antisera from different species were employed, and the antigens were visualized using speciesspecific secondary antisera labeled with FITC (calcitonin; $A$ ) or TRITC (5-HT; $B)$. Complete coincidence of immunostaining was found. Scale markers, 5 $\mu \mathrm{m}$.
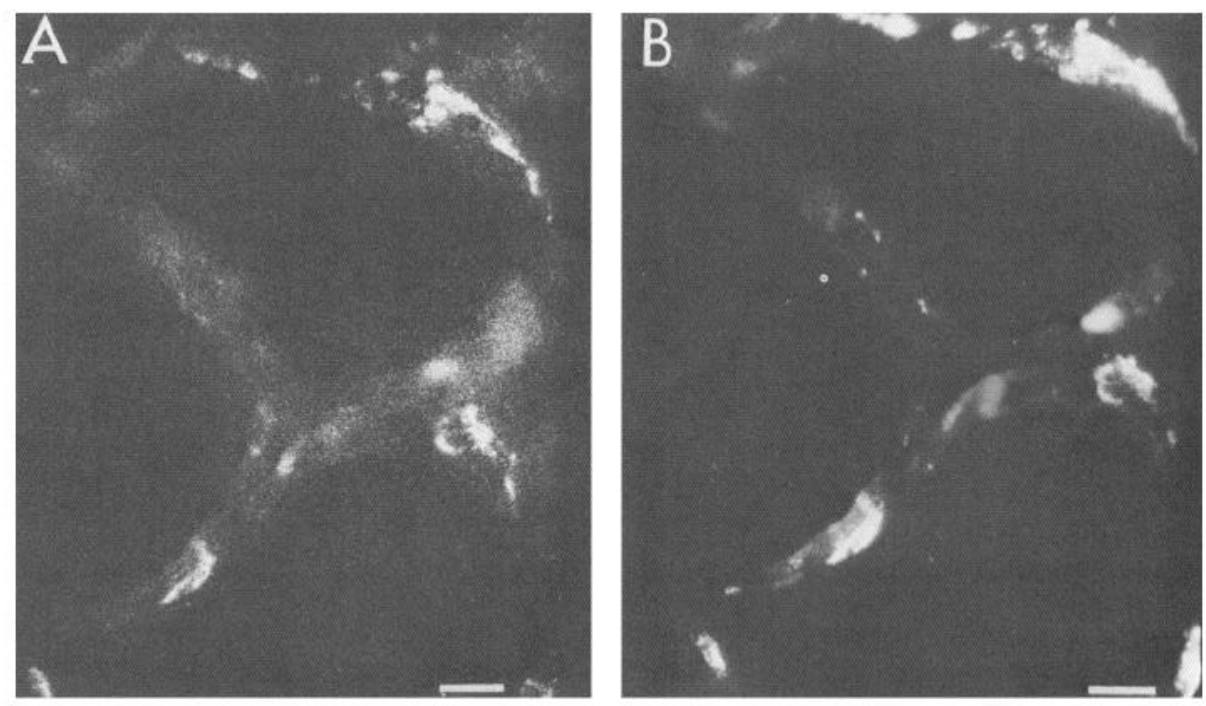

bated with $40 \mathrm{~mm}$ sodium succinate for $20 \mathrm{~min}$. The millimolar extinction coefficient used was $20.5 \mathrm{~cm}^{-1}$, as determined by Ziegler and Doeg (1962).

\section{Results}

Colocalization of calcitonin, 5-HT, and 45kDa SBP

immunoreactivities in parafollicular cells

Calcitonin and 5-HT were immunocytochemically located in frozen sections of sheep thyroid glands. When these 2 antigens were demonstrated simultaneously, both calcitonin and 5-HT immunoreactivities were found to coexist within every parafollicular cell (Fig. 1). No cells were found to express one of these molecules and not the other. Solitary parafollicular cells were occasionally found; however, most of the cells in which 5-HT and calcitonin were costored were located in clusters at the perimeter of follicles. Immunocytochemistry was also used to investigate the distribution in the thyroid of the neurectodermal type of SBP. The hypothesis (Bernd et al., 1981; Gershon and Tamir, 1984) that this protein is costored with 5-HT (and, by extension, calcitonin) in parafollicular cells was tested. An antiserum to the $45 \mathrm{kDa}$ form of rat brain SBP was found to immunolabel large numbers of cells in the sheep thyroid (Fig.
$2 A)$. All of these cells also displayed 5-HT immunoreactivity (Fig. 2B). Coincidence of immunostaining was complete, that is, every cell found to display the immunoreactivity of one of these antigens also displayed the immunoreactivity of the other.

\section{Location of $56 \mathrm{kDa} S B P$ in thyroid nerves}

Affinity-purified antibodies to the $56 \mathrm{kDa}$ form of rat brain SBP did not label parafollicular cells (simultaneously demonstrated by showing 5-HT immunoreactivity; Fig. $3 B$ ); however, these antibodies did bind to nerve fibers in sheep and mouse thyroid glands (Fig. 3, $A, C$ ). These fibers travelled with blood vessels entering the thyroid and extended into interfollicular connective tissue spaces (Fig. $3 A$ ). The $56 \mathrm{kDa}$ SBP-immunoreactive nerve fibers did not emit the fluorescence characteristic of catecholamines when viewed with light at $355-425 \mathrm{~nm}$ (compare Fig. $3, C, D)$. On the other hand, since the material had been fixed with a mixture of $0.05 \%$ glutaraldehyde and $4 \%$ formaldehyde (FAGLU procedure; Furness et al., 1978), the separately located, noradrenergic, sympathetic nerves in the same sections of tissue were found to emit a blue-green aldehyde-induced histofluorescence (Fig. $3 D$ ). The separate identification of noradrenergic and SBP-immunoreactive nerves suggested that the SBP fibers
Figure 2. Simultaneous localization of 5-HT and $45 \mathrm{kDa}$ SBP immunoreactivities in a follicle of the sheep thyroid. Primary antisera from different species were employed, and the antigens were visualized using species-specific secondary antisera labeled with FITC (5-HT; $B)$ or TRITC ( $45 \mathrm{kDa}$ SBP; $A)$. All parafollicular cells displayed immunofluorescence of both 5-HT and 45 $\mathrm{kDa}$ SBP. Scale markers, $5 \mu \mathrm{m}$.
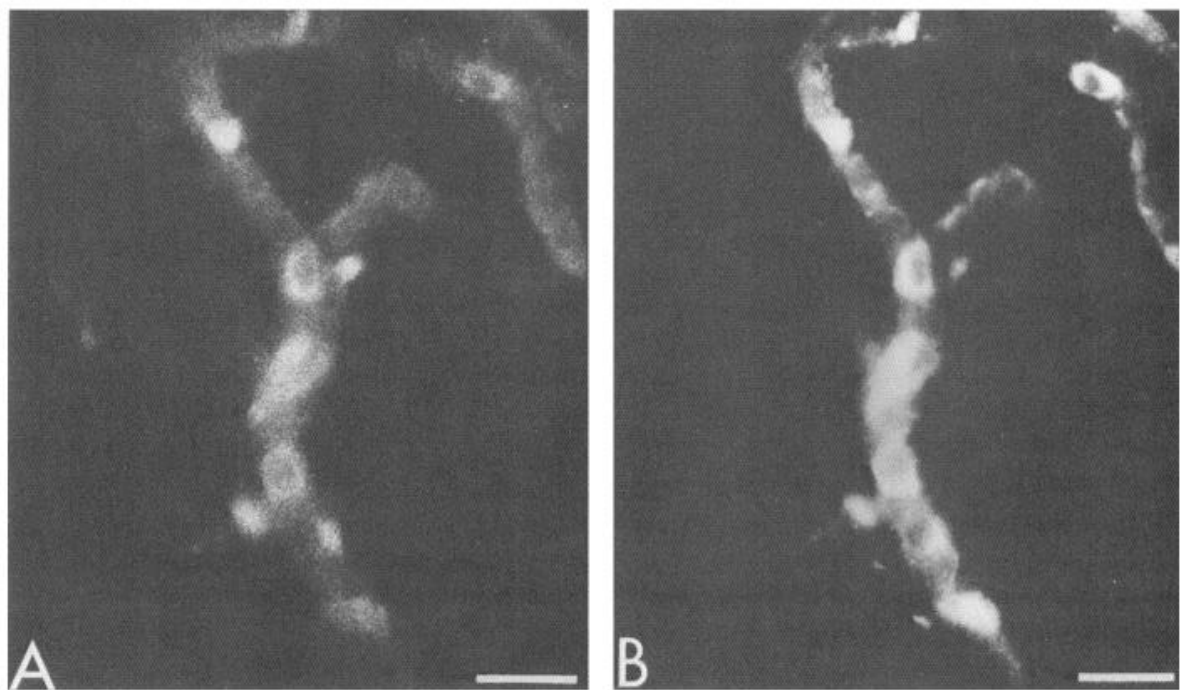

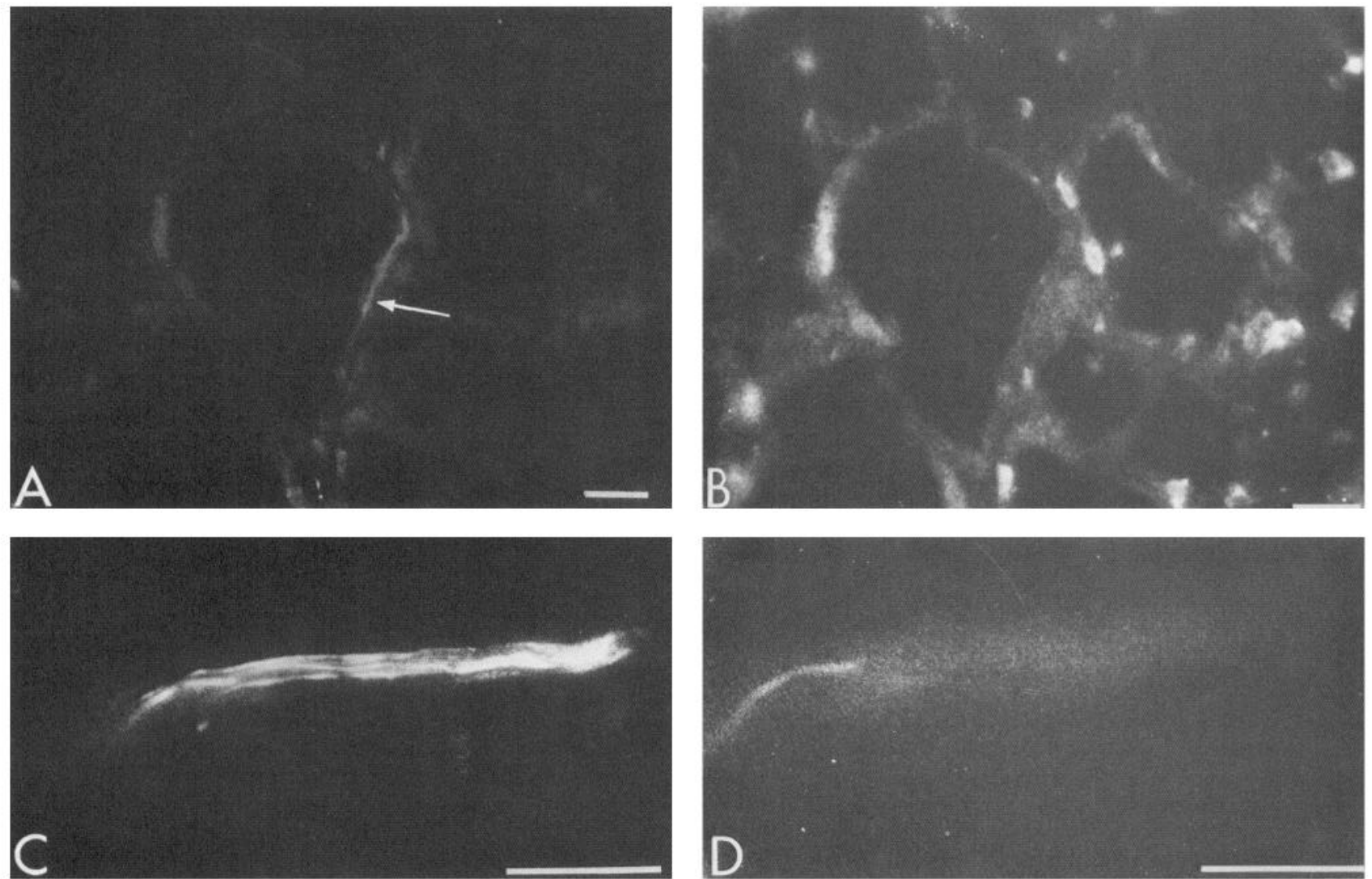

Figure 3. Immunofluorescence of $56 \mathrm{kDa} \mathrm{SBP}$ in the sheep thyroid gland. Immunoreactivity is found in nerve fibers (arrow; $A$ ) but not in parafollicular cells $(B$; stained for 5-HT immunoreactivity). Nerve fibers that display immunofluorescence $(C)$ do not display catecholamine histofluorescence with the FAGLU reaction $(D)$. Scale markers, $10 \mu \mathrm{m}$.

were not sympathetic. In order to confirm this conclusion, the effects on $56 \mathrm{kDa}$ SBP immunoreactivity of chemical sympathectomy with 6-hydroxydopamine were determined in mice. Nerve fibers in mouse thyroid glands continued to be immunostained with antisera to $56 \mathrm{kDa} 2.5 \mathrm{~d}$ after the animals had been treated with $100 \mathrm{mg} / \mathrm{kg}$ of 6-hydroxydopamine. This concentration of 6-hydroxydopamine is known to completely destroy catecholaminergic terminals in the murine thyroid gland (Gershon and Nunez, 1976).

\section{Immunocytochemical investigation of somatostatin in the sheep thyroid}

Somatostatin had been reported to be present in the parafollicular cells of several mammals (Van Noorden et al., 1977; Kameda et al., 1982). The possible presence of this peptide in the parafollicular cells of sheep was therefore investigated immunocytochemically. In contrast to the large numbers of cells expressing the immunoreactivities of 5-HT, calcitonin, and 45 $\mathrm{kDa}$ SBP, somatostatin immunoreactivity was encountered only rarély; however, those few cells that did contain somatostatinlike immunoreactive material also contained 5-HT and occurred as isolated cells within thyroid follicles (data not shown).

\section{Colocalization of 5-HT, calcitonin, and $45 \mathrm{kDa} S B P$ immunoreactivities in the secretory granules of parafollicular cells}

The subcellular localization of 5-HT and calcitonin within parafollicular cells was determined by immunocytochemically staining ultrathin sections of thyroid tissue embedded in LR White.
In order to retain antigenicity, the tissues were not osmicated prior to embedding. As a result, intracellular membranes were not electron dense in these preparations. Although membranes were therefore visible only as negative images, many organelles, such as secretory granules, mitochondria, the Golgi apparatus, lysosomes, and the nucleus could be discerned. Calcitonin immunoreactivity, demonstrated with $20 \mathrm{~nm}$ particles of colloidal gold, was found in almost all of the dense-cored granules of each of the parafollicular cells examined (Fig. 4). Small numbers of randomly distributed gold particles were found over cells other than parafollicular cells and over the nuclei of parafollicular cells when the primary antibody was omitted from the staining protocol. This random scattering of gold particles, consequently, was taken as nonspecific background labeling. The only other organelle, in addition to secretory granules, in which more than background calcitonin immunoreactivity could be demonstrated, was the Golgi apparatus (Fig. 4). It seems likely that this intracisternal calcitonin immunoreactivity in the Golgi apparatus is related to the packaging of calcitonin in newly forming secretory granules.

5-HT immunoreactivity was demonstrated in thin sections with a rat monoclonal antibody to 5 -HT by a technique similar to that used for calcitonin. In the case of 5-HT, secondary antibodies coupled to gold particles, averaging $5 \mathrm{~mm}$ in diameter, were employed. The selection of appropriate species-specific secondary antisera coupled to differently sized gold particles enabled 5-HT and calcitonin to be demonstrated in the same thin sections. About half $(52 \pm 7.4 \% ; n=495)$ of the secretory granules in each parafollicular cell displayed 5-HT immuno- 


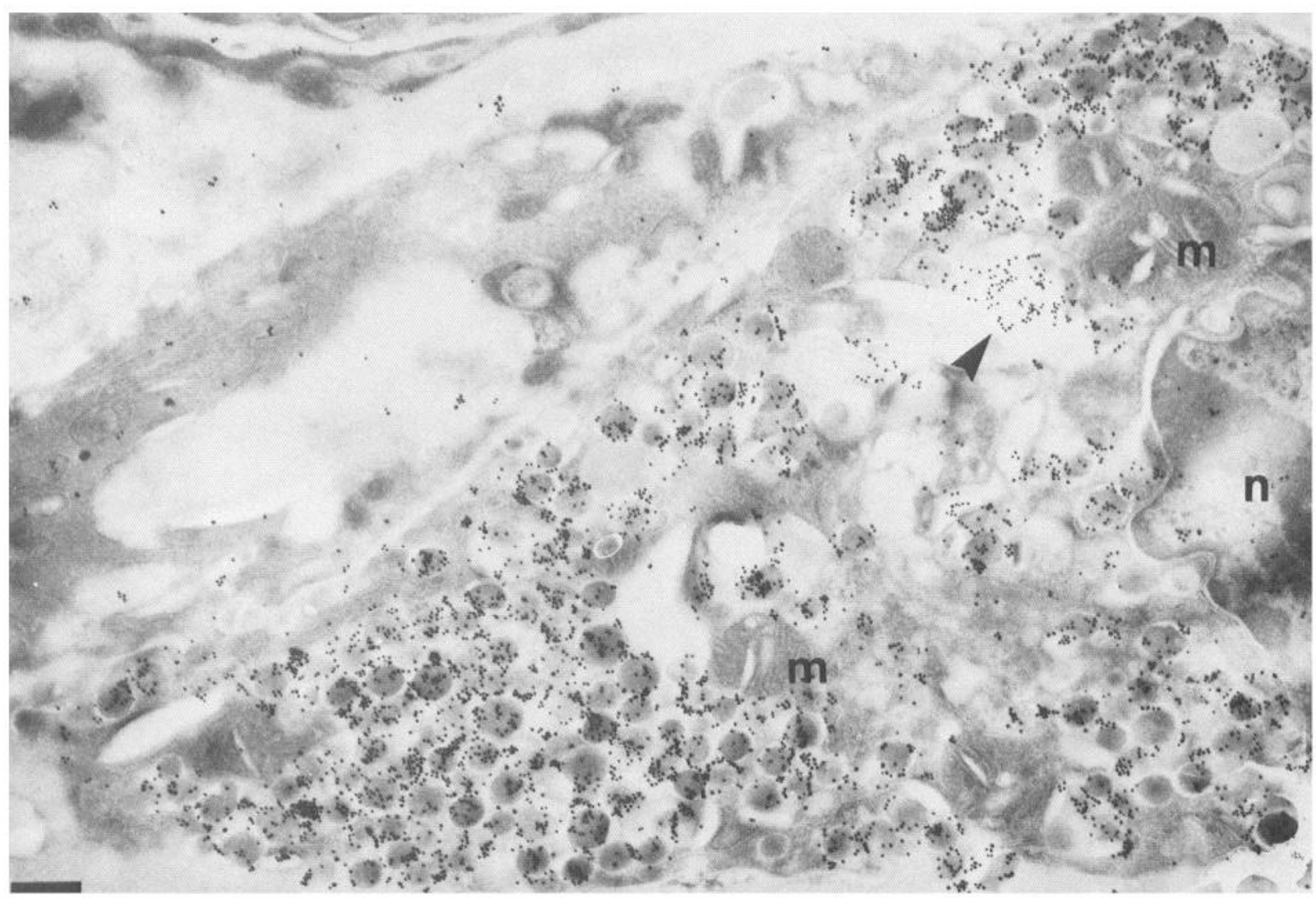

Figure 4. Calcitonin immunoreactivity demonstrated in a parafollicular cell at the electron microscopic level with a secondary antibody labeled with $20 \mathrm{~nm}$ particles of colloidal gold. All of the secretory granules are labeled. Gold particles are also seen over the Golgi apparatus (arrowhead). (Note that the LR White embedding medium does not preserve membranes; therefore, the loss of the membranous Golgic saccules, vacuoles, and vesicles gives the appearance of a large region of empty space in the cytoplasm.) Despite the intense immunostaining, other organelles, such as mitochondria $(\mathrm{m})$ and the nucleus $(\mathrm{n})$, as well as structures outside of the parafollicular cell, show only background levels of labeling with colloidal gold. Membranes cannot be seen because the material has not been osmicated. Scale marker, $0.5 \mu \mathrm{m}$.

reactivity (Fig. $5 A$ ). Virtually all of these 5-HT-immunoreactive granules were also found to contain calcitonin (Fig. 5, $B-D$ ). The proportion of granules with 5-HT immunoreactivity could be raised by using a guinea pig polyclonal anti-5-HT serum; however, in contrast to the rat monoclonal antibody to $5-\mathrm{HT}$, the guinea pig serum gave a high level of nonspecific background staining.

Electron microscopic immunocytochemistry was done with antiserum to $45 \mathrm{kDa} \mathrm{SBP}$ in order to determine if this 5-HT binding protein is colocalized with 5-HT and calcitonin in the secretory granules of sheep parafollicular cells. Sites of primary antibody binding were located with a species-specific secondary antibody coupled to $5 \mathrm{~nm}$ particles of colloidal gold. Since relatively small numbers of gold particles were found over the tissue, the distribution of colloidal gold particles in electron micrographs was analyzed stereologically and compared to the distribution predicted for a random pattern (Fig. 6). The random pattern was approximated by a grid of dots placed over the electron micrographs. The numbers of gold particles and random dots falling over various subcellular components were scored. The distribution of gold particles was significantly different from random $(p<0.001)$; moreover, the only organelle over which more gold particles than random dots were found was the parafollicular cell secretory granule, which was significantly labeled by gold particles $(p<0.001)$. Two or more gold particles were found over $40 \pm 2.4 \%$ of parafollicular cell gran- ules $(n=1381)$. This proportion does not differ significantly from the percentage of secretory granules labeled by antisera to 5-HT. Moreover, when material was doubly labeled with antibodies to 5-HT and $45 \mathrm{kDa}$ SBP, colocalization of both antigens in some, although not all, parafollicular cell secretory granules was found (Fig. 5, $E, F$ ).

\section{Subcellular fractionation of the thyroid}

A crude granule pellet was obtained by differential centrifugation. The 5-HT content of fractions was used as a marker for parafollicular cell secretory granules, succinic dehydrogenase for mitochondria, and $\beta$-glucuronidase for lysosomes. In addition, the fraction was examined morphologically. The crude granule pellet was found to be a heterogeneous fraction, both when assayed with respect to biochemical markers and by morphology (Table 1). Nevertheless, some purification of secretory granules occurred in this fraction, as indicated by an approximately 5.6fold enrichment of 5-HT in the crude granule pellet over that in the whole thyroid homogenate (Table 1). Morphological identification of, and retention of calcitonin by, parafollicular granules in the fraction was confirmed by demonstrating their calcitonin immunoreactivity (not illustrated). The granules occupied about $9 \%$ of the volume of the crude granule pellet (determined by point-count planimetry; $n=1192$ points). The crude granule pellet was used as the starting material for granule purification 

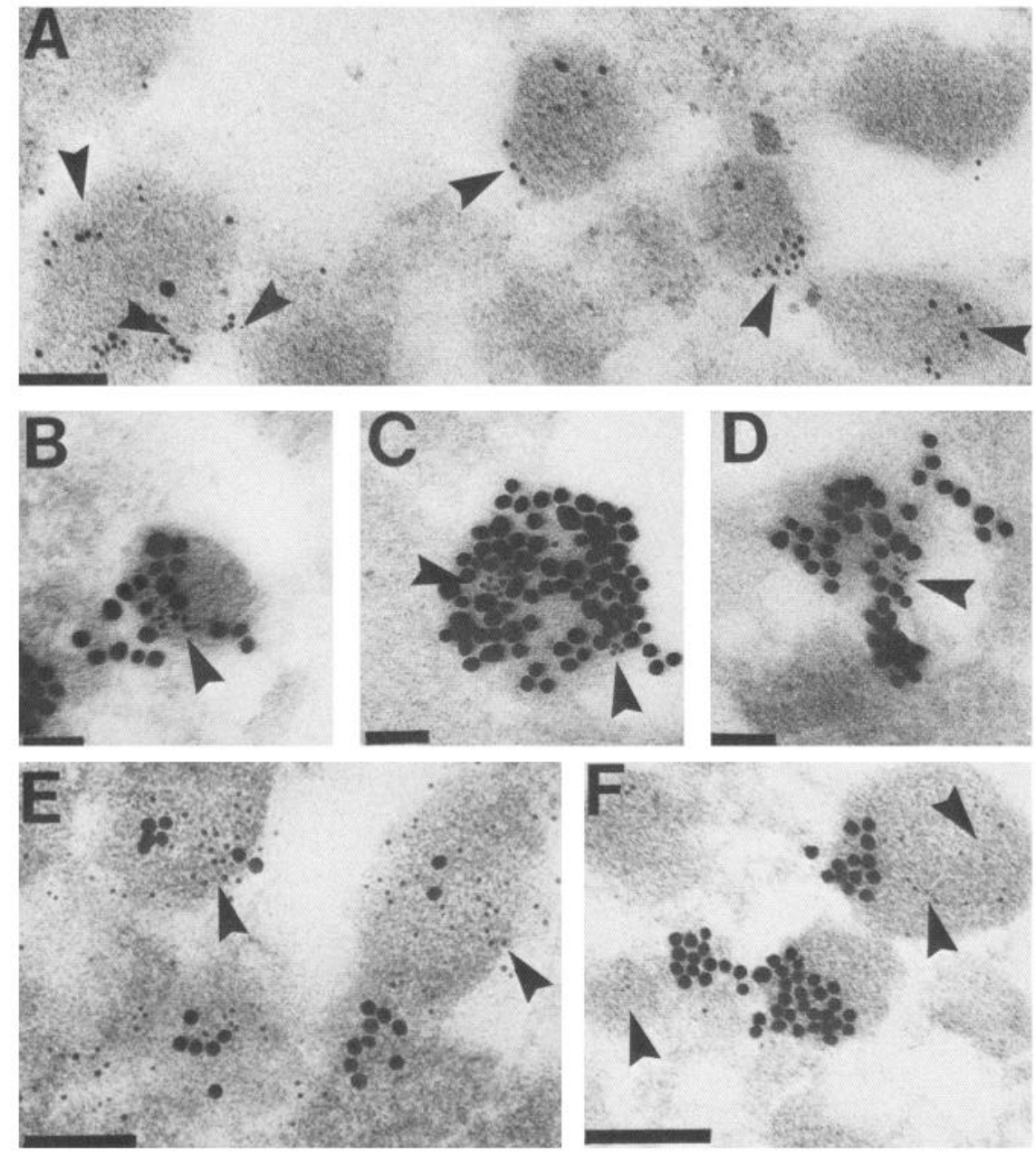

Figure 5. A, 5-HT immunoreactivity (arrowheads) demonstrated in parafollicular cell granules at the electron microscopic level with a secondary antibody labeled with $5 \mathrm{~nm}$ particles of colloidal gold. About half of the granules display immunoreactivity, which is found over no other region of the cell. The marker $=0.1 \mu \mathrm{m} . B-D, C o-$ localization of the immunoreactivies of 5-HT and calcitonin in parafollicular cell granules. 5-HT immunoreactivity (arrowheads) is shown with $5 \mathrm{~nm}$ and calcitonin immunoreactivity with 20 $\mathrm{nm}$ particles of colloidal gold. Scale markers, $0.1 \mu \mathrm{M}$. $E$ and $F$, Colocalization of the immunoreactivites of 5-HT and $45 \mathrm{kDa}$ SBP in parafollicular cell granules. 5-HT immunoreactivity (arrowheads) is shown with $5 \mathrm{~nm}$ and 45 $\mathrm{kDa}$ SBP immunoreactivity with $15 \mathrm{~nm}$ particles of colloidal gold. Scale markers, $0.1 \mu \mathrm{m}$.

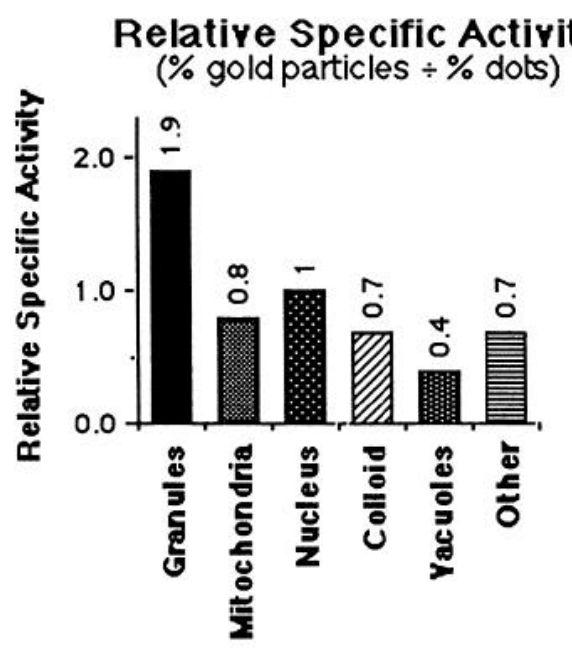

\section{Chi Square Values}

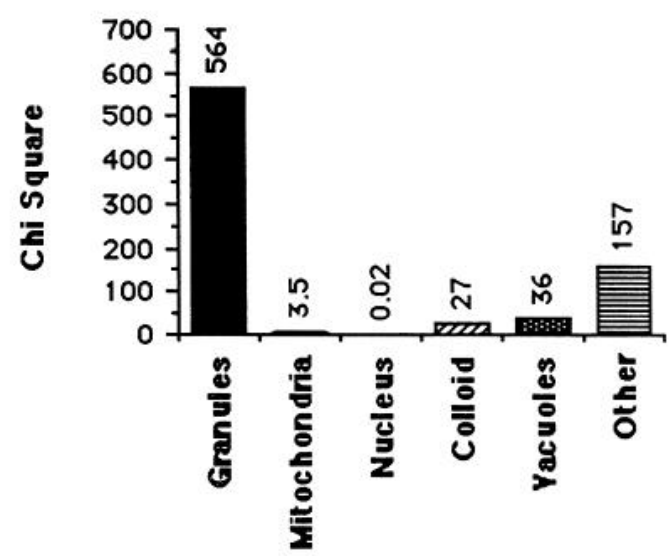

Figure 6. Statistical analysis of the distribution of immunogold particles over subcellular components of parafollicular cells following exposure to antiserum to $45 \mathrm{kDa}$ SBP. The incidence of gold particles falling over each component was compared with that of random dots placed over micrographs of the tissue. Relative specific activity (graph at left) of each subcellular component is defined as the percent of gold particles (total number counted $=2763) \div$ the percentage of random dots (total number counted, 1430) over each component. A specific activity significantly greater than 1 (more gold particles than random dots) indicates labeling of the component by immunogold. To establish significance, the gold and dot distributions were compared by a $\chi^{2}$ analysis (right), in which the dots were taken as the distribution expected for a random alignment of particles over the tissue. The distribution of gold particles is nonrandom $(p<0.001)$. When the relative specific activity of parafollicular granules (1.9) is compared with that of the aggregate of all other components $(0.7)$ the difference is significant $(p<0.001)$. Parafollicular cell granules therefore contain $45 \mathrm{kDa}$ SBP immunoreactivity. 

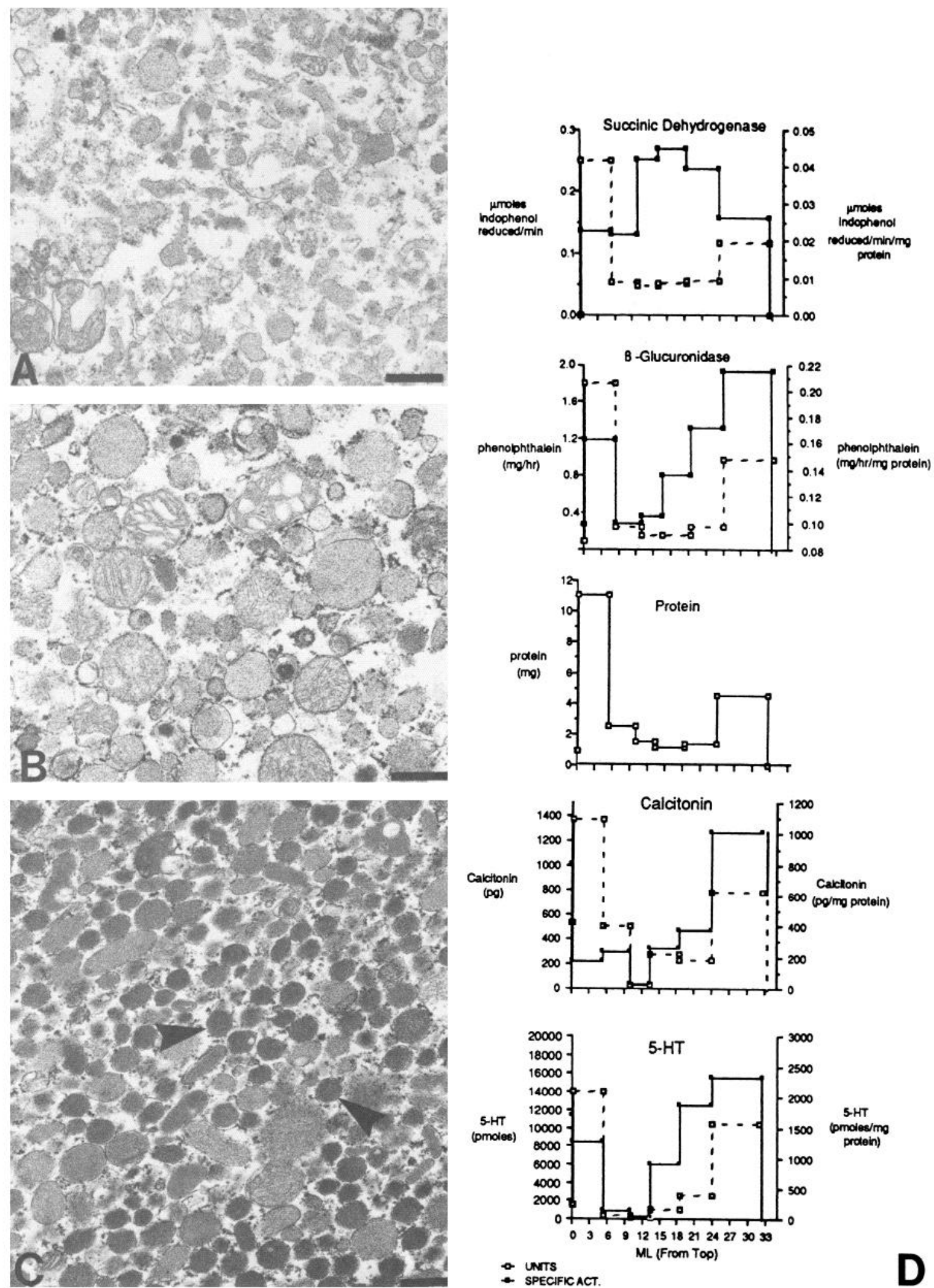

Figure 7. $A-C$, Electron micrographs of fractions obtained from separations of thyroid organelles on a Percoll density gradient. The gradient was divided into 3 parts by volume, the upper $15 \%(A)$, the middle $60 \%(B)$, and the lowest $25 \%(C)$. Organelles that resemble parafollicular cell granules (arrowheads) are only found in the lowest, "vesicular" $(C)$ fraction. These structures occupy about $30 \%$ of the particulate volume of this fraction. Scale markers, $0.5 \mu \mathrm{M}$. $D$, Distribution of succinic dehydrogenase activity, $\beta$-glucuronidase activity, total protein, calcitonin immunoreactivity, and 5-HT in a Percoll density gradient layered with the crude granule pellet obtained from a thyroid homogenate. Specific activity and total recovered units of each marker are plotted. Fractions of approximately equal volume were collected and are shown on the abscissa. The top of the gradient is at the left in each graph. 
and for the analysis of the granular uptake of ${ }^{3} \mathrm{H}-5-\mathrm{HT}$ (see below).

\section{Purification of parafollicular cell secretory granules on Percoll gradients}

Parafollicular cell secretory granules were further purified from the crude granule pellet by centrifugation to equilibrium on a linear density gradient of Percoll. The distributions of 5-HT and calcitonin immunoreactivity on these gradients were similar (Fig. 7D). A relatively dense "vesicular" fraction (1.08-1.15 $\mathrm{g} / \mathrm{ml}$ ) was found in which each was enriched (Fig. $7 \mathrm{c}$ ), and both of these markers were also found in the supernatant of the gradient. The specific activity of 5-HT $(\sim 2500 \mathrm{pmol} / \mathrm{mg}$ protein) and calcitonin immunoreactivity $(\sim 1 \mathrm{ng} / \mathrm{mg}$ protein) were highest in the "vesicular" fraction, which contained $22 \pm 5 \%$ of the $5-\mathrm{HT}$ and $20 \%$ of the calcitonin immunoreactivity applied to the gradient. $\beta$-Glucuronidase, but not succinic dehydrogenase, was also concentrated in the 5-HT-enriched "vesicular" fraction. The structures that were morphologically identified as parafollicular cell secretory granules occupied $31 \%$ of the particulate volume of the "vesicular" fraction as determined by point-count planimetry of electron micrographs $(n=1223$ points), a 3.4-fold purification of the granules over their concentration in the more heterogeneous crude granule pellet.

\section{Radioautographic analysis of ${ }^{3} \mathrm{H}-5-\mathrm{HT}$ uptake}

Parafollicular cell granules were tested for their ability to take up and retain ${ }^{3} \mathrm{H}-5-\mathrm{HT}$. The crude granule pellet was incubated with ${ }^{3} \mathrm{H}-5-\mathrm{HT}(6 \mu \mathrm{M})$ for $10 \mathrm{~min}$ at $37^{\circ} \mathrm{C}$, washed, and applied to a Percoll gradient as described above. The location of the ${ }^{3} \mathrm{H}-5-\mathrm{HT}$ retained by isolated subcellular components was assessed by electron microscopic radioautography. Quantitation of exposed radioautographs demonstrated that parafollicular cell granules, and no other components, were significantly labeled by ${ }^{3} \mathrm{H}-5-\mathrm{HT}$ ( $p<0.001$; Fig. 8 ). ${ }^{3} \mathrm{H}-5$-HT present in the vesicular fraction was reduced when the crude granular pellet was incubated with ${ }^{3} \mathrm{H}-5-\mathrm{HT}$ at $4^{\circ} \mathrm{C}$ (to $54 \pm 3 \%$ of control; $n=4$ ) or in the presence of $10 \mu \mathrm{M}$ reserpine (to $18 \pm 4 \%$ of control; $n=$ $4 ; p<0.01$ vs $4^{\circ} \mathrm{C}$ or control).

\section{Purification of parafollicular cell granules on sequential metrizamide gradients}

In order to obtain intact parafollicular cell secretory granules in a better yield and to effect a better separation of granules from lysosomes than could be achieved with Percoll gradients, 2 sequential discontinuous gradients of metrizamide were used. The primary gradient was not centrifuged to equilibrium. Morphologic inspection of material collected at the interfaces between

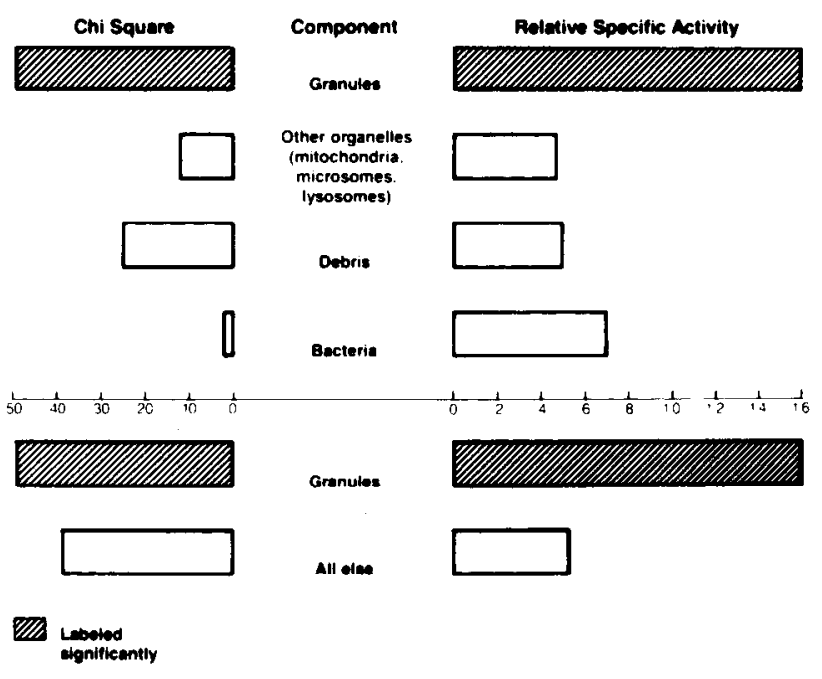

Figure 8. Analysis of the distribution of radioautographic silver grains over components found in the vesicular fraction of Percoll gradients. Probability circles, equal in diameter to 1.5 times the half distancethe distance from a radioactive source within which $50 \%$ of silver grains will lie (Salpeter et al., 1969) - were drawn around each silver grain and the components within the circle were scored. The distribution of items falling within random circles was also obtained. Relative specific activity of a component was defined as the frequency of that component falling within the circles drawn around silver grains divided by the frequency of finding that same component within the random circles (Williams, 1969). The grain and circle distributions for all components were compared by means of a $\chi^{2}$ test. If the relative specific activity of an item was $>1$, and the grain and circle distributions were significantly different, the component was considered labeled. Only organelles with the morphological appearance of parafollicular cell granules were labeled.

different concentrations of metrizamide in the primary gradient revealed that subcellular organelles were distributed in this gradient according to size (Fig. 11). This permitted the use of a second gradient, centrifuged to equilibrium to separate subcellular constituents according to their density (Fig. 12).

In the primary gradient, 5 -HT was concentrated $[3.1 \pm 0.3$ $(n=8) \mathrm{nmol} / \mathrm{mg}$ protein; $41 \pm 1.7 \%$ of the 5 -HT applied to the gradient] in a single sedimentable "vesicular" fraction (fraction $\mathrm{C}_{1}$, Fig. 9). The peak concentration of 5-HT was separated from peak activities of $\beta$-glucuronidase and succinic dehydrogenase (fraction $E_{1}$, Fig. 9). The specific activity of $\beta$-glucuronidase in the fraction in which 5 -HT was most concentrated was less than that found in the crude granule pellet (75\%) and contained only $16 \pm 2 \%$ of the total $\beta$-glucuronidase activity recovered on the primary gradient. The succinic dehydrogenase activity in the 5-HT-enriched "vesicular" fraction was only one-

Table 1. Markers in the crude granule fraction

\begin{tabular}{|c|c|c|c|}
\hline \multirow[b]{2}{*}{ Marker } & \multicolumn{2}{|l|}{ Amount/activity } & \multirow{2}{*}{$\begin{array}{l}\text { Recovery } \\
(\%)\end{array}$} \\
\hline & Homogenate & Crude granule fraction & \\
\hline $5-\mathrm{HT}^{a}$ & $327 \pm 58$ & $1847 \pm 196$ & $39 \pm 5$ \\
\hline Succinic dehydrogenase ${ }^{b}$ & $6.4 \pm 0.7$ & $34 \pm 3.0$ & $18 \pm 2$ \\
\hline$\beta$-glucuronidase ${ }^{c}$ & $0.08 \pm 0.01(11)$ & $0.15 \pm 0.02(13)$ & $11 \pm 1$ \\
\hline
\end{tabular}

${ }^{a} \mathrm{pmol} / \mathrm{mg}$ protein.

${ }^{b} \mathrm{nmol}$ indophenol $\mathrm{reduced} / \mathrm{min} / \mathrm{mg}$ protein.

' $\mathrm{mg}$ phenolphthalein liberated/mg protein/hr. Recovery of protein in the crude granule pellet was $6.4 \pm 0.6 \%(n=8)$. 

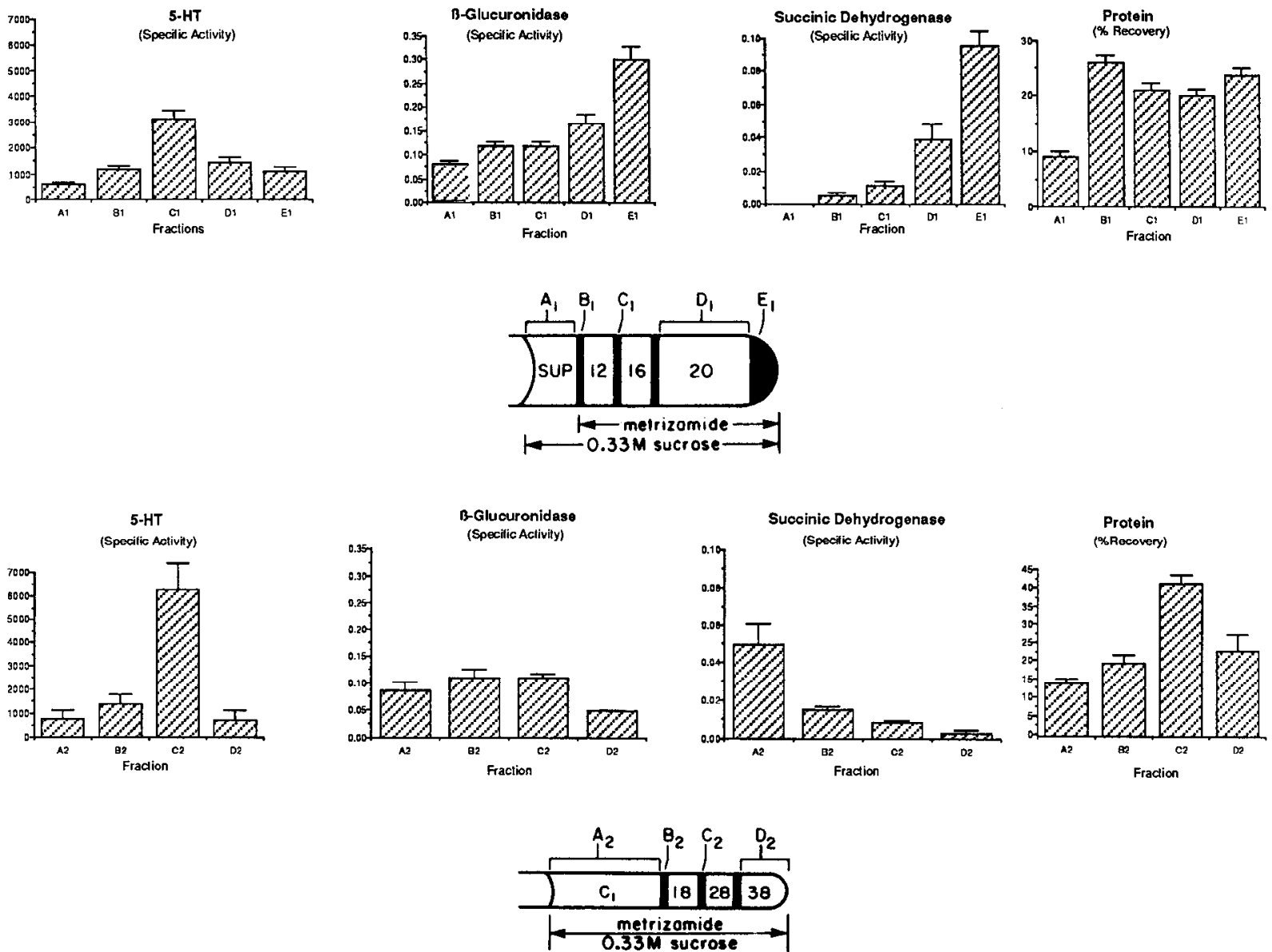

Figure 9. Purification of parafollicular cell granules on 2 sequential metrizamide gradients. The crude granule pellet obtained from a thyroid homogenate was layered over an initial metrizamide gradient and spun at $9700 \times g$ for $44 \mathrm{~min}$. The position and the nomenclature of the resultant fractions is shown in the upper diagram of a centrifuge tube. Fraction $C_{1}$ was layered on a second, more dense, metrizamide gradient and spun to equilibrium. The position and the nomenclature of the resultant fractions is shown in the lower diagram of a centrifuge tube. The graphs in the upper portion of the figure show the distribution of $5-\mathrm{HT}, \beta$-glucuronidase activity, succinic dehydrogenase activity, and total protein in the initial gradient, and the graphs in the lower portion of the figure show the distributions of the same markers in the secondary gradient. 5-HT, but not $\beta$-glucuronidase or succinic dehydrogenase, concentrates in fraction $C_{1}$ of the primary and $C_{2}$ of the secondary gradient. These fractions were thus identified as "vesicular." Specific activities are expressed as follows: 5 -HT, $\mathrm{pmol} / \mathrm{mg}$ protein; $\beta$-glucuronidase, $\mathrm{mg}$ phenolphthalein released/hr/mg protein; succinic dehydrogenase, $\mu \mathrm{mol}$ indophenol reduced $/ \mathrm{min} / \mathrm{mg}$ protein.

Figure 10. Summary of granule purification by the methods used. The relative specific activity (specific activity of the fraction $\div$ specific activity of the homogenate) of 5-HT, $\beta$-glucuronidase, and succinic dehydrogenase $(S D H)$ in various fractions in plotted. $H$, homogenate; $C G P$, crude granular pellet; $P($ "ves"), the "vesicular" fraction obtained from Percoll gradients; $M(C l)$ and $M(C 2)$, the "vesicular" fractions obtained from primary $(\mathrm{C} 1)$ and secondary (C2) metrizamide gradients.

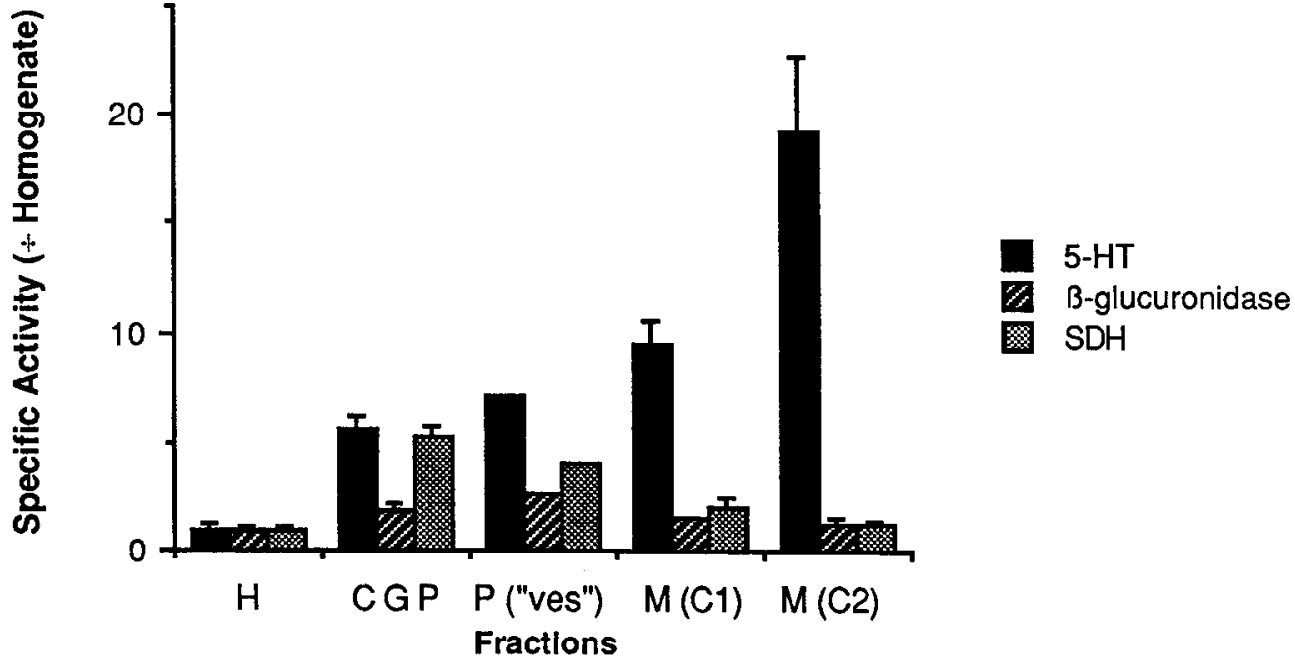



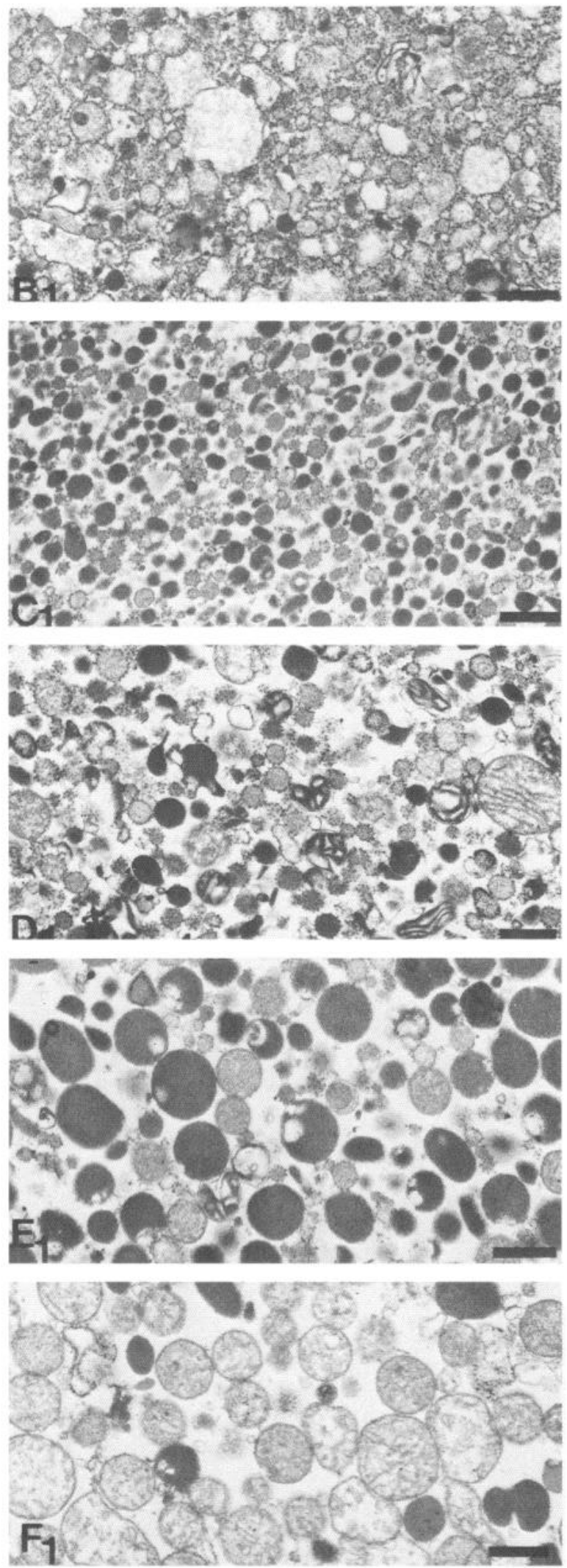

Figure 11. Representative electron micrographs of fractions of the primary metrizamide gradient used to separate subcellular components of thyroid homogenates. Fraction A (not shown) was the supernatant. Structures with the morphological appearance of the secretory granules of parafollicular cells were mainly found in fraction $C_{1}$. This fraction contained microsomes but few lysosomes or mitochondria. These latter organelles were found lower in the gradient, at different levels of fraction $\mathrm{E}_{1}$ of Figure 9. Scale markers, $0.5 \mu \mathrm{m}$.
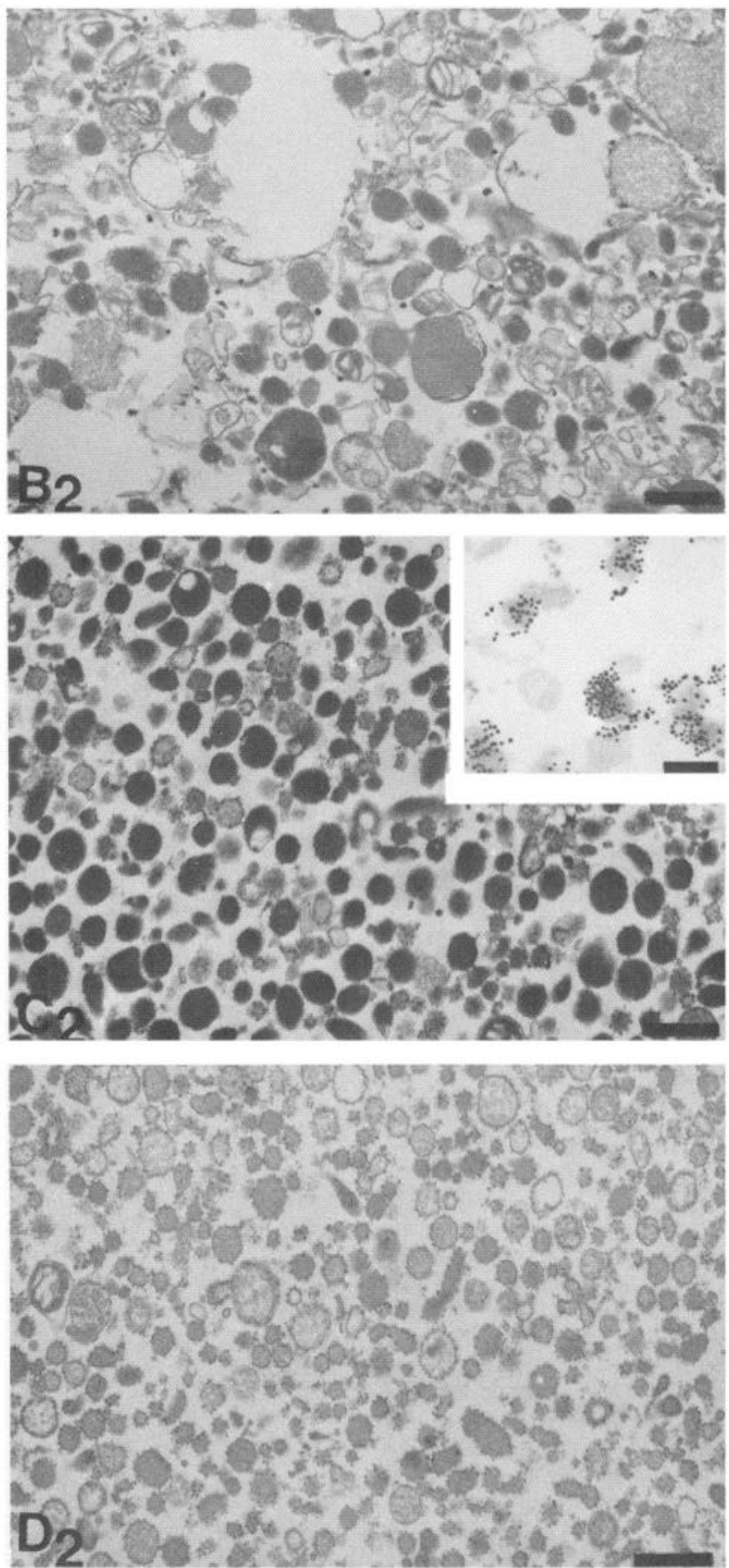

Figure 12. Representative electron micrographs of fractions of the secondary metrizamide gradient used to separate subcellular components found in fraction $\mathrm{C}_{1}$ of the primary gradient (shown in Fig. 11 above). This second, more dense gradient was centrifuged to equilibrium. Structures with the morphological appearance of the secretory granules of parafollicular cells were found in fraction $\mathrm{C}_{2}$. Inset, Calcitonin immunoreactivity has been localized using a rabbit primary antiserum and a species-specific secondary antibody coupled to particles of colloidal gold that averaged $20 \mathrm{~nm}$ in diameter. The fractions were not osmicated and were embedded in LR White for postembedding immunostaining. As a result, membranes cannot be seen and the density of tissue components is low. The detection of the calcitonin marker confirms the identification of parafollicular cell granules in gradient fractions and indicates that peptide content is retained through the steps involved in granule isolation. Although some contamination of $\mathrm{C}_{2}$ by microsomes remains, the proportion of this granular fraction occupied by microsomes has been reduced and the bulk of the microsomes that were in fraction $C_{1}$ are now found in fraction $D_{2}$. Scale markers, 0.5 $\mu \mathrm{M}$. 


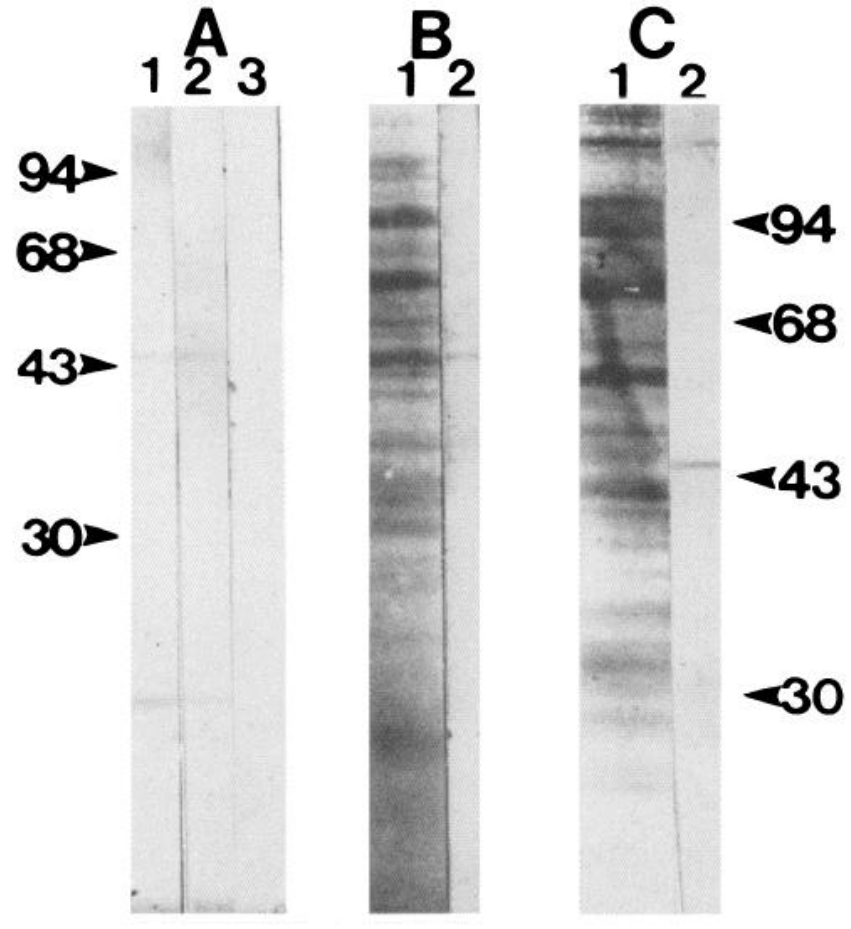

Figure 13. Immunoblot analysis of the proteins of highly purified parafollicular cells $(A)$, the "crude granular pellet" $(B)$, and the most enriched fraction of parafollicular cell granules - fraction $C_{2}$ of the secondary metrizamide gradient $(C)$ (see Fig. 12). Parafollicular cells were purified by the method of Bernd et al. (1981). The parafollicular cell proteins were separated by SDS-PAGE and blotted onto nitrocellulose paper. Immunoreactivity was demonstrated with rabbit primary antisera to 45 or $56 \mathrm{kDa}$ SBP and a biotinylated goat anti-rabbit secondary antiserum visualized with avidin-alkaline phosphatase. $(A$, lane $I$, antiserum to $45 \mathrm{kDa} \mathrm{SBP}$; lane 2, antiserum to $45 \mathrm{kDa}$ SBP diluted 5-fold; lane 3 . antiserum to $56 \mathrm{kDa}$ SBP; $B$. lane 1 , amido-black stained proteins of the "crude granular pellet"; lane 2 , antiserum to $45 \mathrm{kDa} \mathrm{SBP}$; $C$, lane $I$, amido-black-stained proteins of the enriched parafollicular cell granules; lane 2, antiserum to $45 \mathrm{kDa}$ SBP.) Immunoreactivity corresponding in mobility on SDS-PAGE gels to a $45 \mathrm{kDa}$ standard is present in all preparations ( $A$, lanes $I$ and $2 ; B$, lane $2 ; C$, lane 2$)$; however, in the whole cells $(A)$ an additional band of lower molecular weight can also be seen. Dilution of the antiserum $(A$, lane 2$)$ diminishes the immunoreactivity. No immunostaining of proteins from whole parafollicular cells is seen when blotted proteins are exposed to antiserum against the $56 \mathrm{kDa}$ SBP $(A$, lane 3$)$. The faintly stained bands apparent in $C$ (lane 2) are also present when the primary antiserum is omitted and thus represent nonspecific staining by the secondary antibody.

third that of the crude granule pellet. Only $8 \pm 1 \%$ of the total succinic dehydrogenase activity applied to the gradient was recovered in the "vesicular" fraction.

Granules were further purified by subjecting the fraction of the primary gradient richest in 5-HT $\left(\mathrm{C}_{1}\right)$ to equilibrium density centrifugation on a second metrizamide gradient. When this was done, 5-HT was found to be concentrated in a single sedimentable fraction (fraction $\mathrm{C}_{2}$, Fig. 9), which contained $80 \pm$ $5 \%$ of the total 5 -HT applied to the second gradient. The 5-HT concentration of this fraction, $6.3 \pm 1.1 \mathrm{nmol} / \mathrm{mg}$ protein, was 2 -fold that found in fraction $C_{1}$ of the primary gradient and 3.5fold that found in the crude granule pellet (Fig. 10). Moreover, neither the $\beta$-glucuronidase, nor the succinic dehydrogenase activity present in the secondary gradient copurified with 5-HT (Figs. 9 and 10). Inspection of gradient fractions by electron microscopy confirmed that the primary gradient fraction, $\mathrm{C}_{1}$, and the secondary gradient fraction, $\mathrm{C}_{2}$, in which $5-\mathrm{HT}$ was most concentrated (Fig. 10), also had the highest concentration of parafollicular cell secretory granules in their respective gradients (Figs. 11 and 12). The presence of calcitonin-containing granules in fraction $\mathrm{C}_{2}$ and their morphological identification were confirmed immunocytochemically (Fig. $12 \mathrm{C}_{2}$, inset). Parafollicular cell secretory granules composed $\sim 30 \%(n=936)$ of the occupied space in fraction $C_{1}$ and $\sim 62 \%(n=1170)$ of the occupied space in fraction $\mathrm{C}_{2}$. The majority of the microsomes that contaminated the primary gradient fraction $\left(C_{1}\right)$ in which 5-HT and parafollicular cell secretory granules were concentrated were separated from the parafollicular cell secretory granules on the second metrizamide gradient. Microsomes were recovered mainly in the pellet (fraction $\mathrm{D}_{2} ;$ Fig. 12) of the secondary gradient, which contained little 5-HT (Fig. 9).

\section{SBP in isolated parafollicular cell granules}

SBP activity was measured in the crude granular pellet obtained from thyroid homogenates and in the partially purified granules isolated from the primary metrizamide gradient. SBP was identified by its ability to bind ${ }^{3} \mathrm{H}-5-\mathrm{HT}$ specifically, by the dependence of this binding on $\mathrm{Fe}^{+2}$, and by the ability of reserpine $(10 \mu \mathrm{M})$ to inhibit binding - all characteristics of brain SBP (Tamir et al., 1976; Gershon and Tamir, 1984). It was not possible to get enough protein for assay from fraction $\mathrm{C}_{2}$ of the secondary metrizamide gradient; nevertheless, SBP activity in the "vesicular" fraction $\left(\mathrm{C}_{1}\right)$ of the primary gradient $\left(300\right.$ pmol of ${ }^{3} \mathrm{H}-5$ HT bound/mg protein) was enriched 4 -fold over that in the crude granular fraction (71 pmol of ${ }^{3} \mathrm{H}-5$-HT bound $/ \mathrm{mg}$ protein). As is true of brain SBP, all of the 5-HT-binding activity was found in the protein precipitated by ammonium sulfate at $0-30 \%$ saturation. Binding of ${ }^{3} \mathrm{H}-5-\mathrm{HT}$ was reduced by over $83 \pm 6 \%$ in the granular fractions in the absence of $\mathrm{Fe}^{+2}$ and by about the same amount in the presence of $10 \mu \mathrm{M}$ reserpine. Virtually no ${ }^{3} \mathrm{H}-5-\mathrm{HT}$ was bound by the protein precipitated from granular fractions by ammonium sulfate at $30-60 \%$ saturation $\left(6 \mathrm{pmol}{ }^{3} \mathrm{H}-5-\mathrm{HT}\right.$ bound $/ \mathrm{mg}$ protein $)$. These data indicate that SBP, like 5-HT, is enriched by the purification of parafollicular cell granules.

The idea that SBP is present in parafollicular cell granules was examined further by staining immunoblots of the proteins present in highly purified parafollicular cells and in the granular fractions with antisera raised against 45 and $56 \mathrm{kDa}$ SBP purified from rat brain (Fig. 13). SBP-immunoreactive material comigrating with a $45 \mathrm{kDa}$ standard was detected in the immunoblots of purified parafollicular cells (Fig. 13A). In addition, a second band of immunoreactivity was also found corresponding to about $20 \mathrm{kDa}$. SBP immunoreactivity was found to diminish when the primary antiserum was diluted 5 -fold (Fig. 13A, lane 2). No staining of any protein was found when blots were exposed to affinity-purified antisera directed against $56 \mathrm{kDa}$ SBP (Fig. 13A, lane 3). Similar immunoblots, made with crude (Fig. 13B) and purified parafollicular granular fractions (Fig. 13C), revealed immunostaining of a protein corresponding to a molecular weight of $45 \mathrm{kDa}$ but no immunoreactivity of lower-molecular-weight proteins was seen. Thyroid parafollicular granules thus contain a protein that is of the same size as one of the forms of brain SBP and that reacts with antisera to that brain protein.

\section{Parafollicular cell granules contain little or no ATP}

The concentration of ATP in metrizamide gradient fractions was assayed using a luciferin-luciferase system (Fig. 14). Purification of parafollicular cell secretory granules was not accom- 
panied by a parallel concentration of ATP. In fact, although the distribution of ATP in the primary metrizamide gradient was similar to that of 5-HT, ATP and 5-HT did not copurify in the second gradient (Fig. 14, lower graph). The peak concentration of ATP was found in a fraction of the secondary gradient that was lighter than the fraction in which 5-HT was most concentrated. More importantly, the concentrations in the "vesicular" fractions of both gradients were quite low; thus, the 5-HT:ATP molar ratio in the primary gradient fraction $\left(\mathrm{C}_{1}\right)$ was high (ratio $=17 \pm 3$; [ATP] $=92 \pm 16 \mathrm{ng} / \mathrm{mg}$ protein) and was not reduced in the granular fraction of the secondary gradient $\left(\mathrm{C}_{2}\right)$ ratio $=26 \pm 4$; $[\mathrm{ATP}]=86 \pm 6 \mathrm{ng} / \mathrm{mg}$ protein) as the parafollicular cell secretory granules became further enriched.

Confirmation that parafollicular cell secretory granules were relatively poor in their concentration of ATP was obtained morphologically. Fragments of sheep thyroid and mouse adrenal glands were subjected to the uranaffin reaction, which is an electron microscopic cytochemical procedure that demonstrates high concentrations of ATP in cells such as platelets and adrenal pheochromocytes (Richards and DaPrada, 1977). The murine adrenal medulla served as a positive control. There was heavy uranaffin staining of the cores of the chromaffin granules of pheochromocytes (Richards and Da Prada, 1977). The murine addition, the 5-HT-containing granules of platelets, found in adrenal blood vessels were also highly reactive (Fig. 15B). In contrast, parafollicular cell secretory granules of the sheep thyroid remained unstained (Fig. $15 C$ ).

\section{Discussion}

The current experiments were undertaken to test the hypothesis that the neural crest-derived thyroid parafollicular cell has properties analogous to those of serotonergic neurons. If so, advantage could be taken of the large and identifiable parafollicular cell granules to isolate and characterize a 5-HT storage orangelle that has characteristics that might also characterize serotonergic synaptic vesicles. Initial studies used immunocytochemical techniques to define the 5-HT-related properties of sheep parafollicular cells. Frozen sections of sheep thyroid were treated with antisera to 5-HT, SBP (45 and $56 \mathrm{kDa}$ forms), and calcitonin in order to test the proposal (Bernd et al., 1979, 1981) that these compounds are costored in the same parafollicular cells and in the same parafollicular granules. We also wished to rule in or out the possibility that there are subsets of parafollicular cells or granules that can be distinguished by the presence or absence of one or another of these substances. Almost all of the parafollicular cells, identified by their calcitonin immunoreactivity, were also found to have 5-IIT immunoreactivity; moreover, 5-HT and $45 \mathrm{kDa}$ SBP immunoreactivities were colocalized. Thus, there cannot be a significant number of subsets of parafollicular cell in the sheep thyroid. There was an extremely rare second type of parafollicular cell, in which 5-HT immunoreactivity was found to be colocalized with that of somatostatin; however, in view of the extremely small number of such cells, it can be concluded that the sheep thyroid has a population of parafollicular cells that is essentially homogeneous with respect to the molecules studied and therefore suitable for the subcellular isolation of 5-HT storage granules. In this sense the thyroid parafollicular cell is different from adrenal medullary chromaffin cells, of which there are 2 different types: one storing epinephrine and the other storing norepinephrine (Coupland and Hopwood, 1966). Thus, studies of isolated adrenal chro-
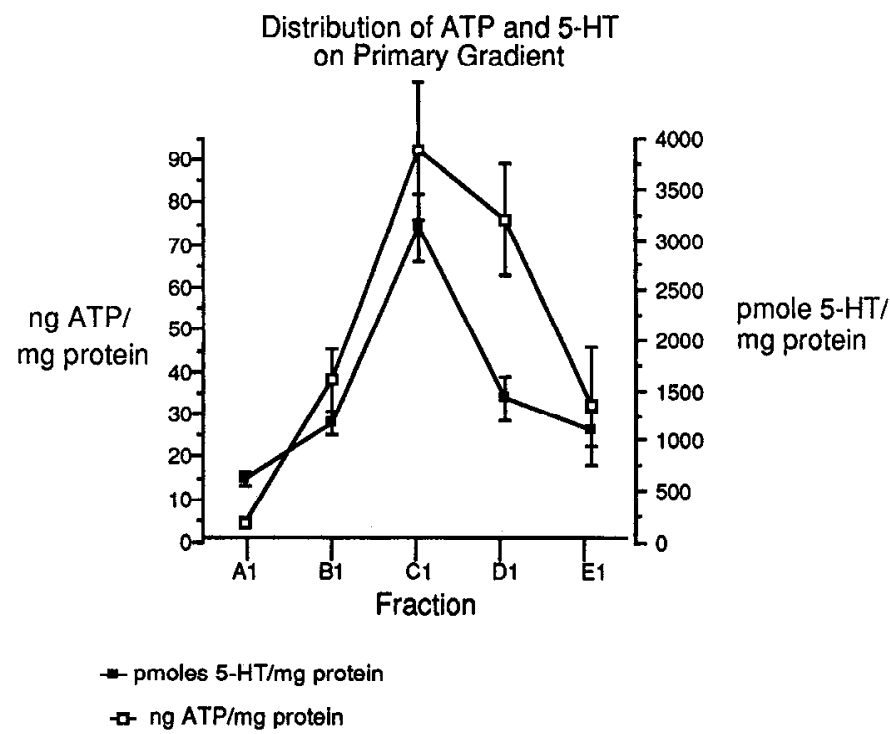

Distribution of ATP and 5-HT

on Secondary Gradient

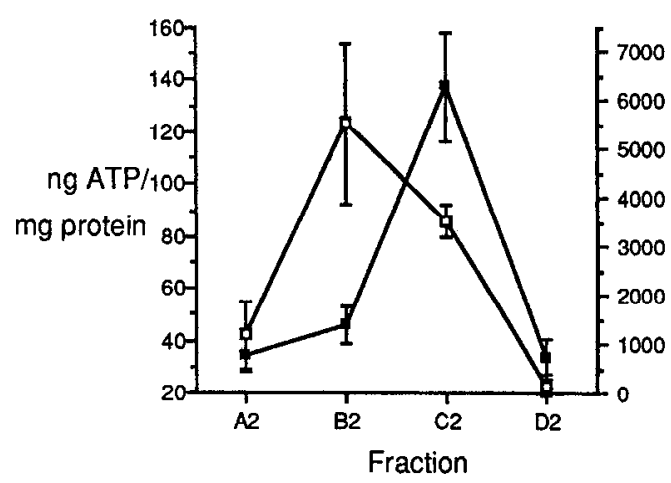

pmoles 5-HT/ mg protein

Figure 14. Distribution of ATP and 5-HT in the primary and secondary metrizamide gradients used to separate subcellular components of thyroid homogenates. In the primary gradient (top graph), the highest concentrations of both ATP and 5-HT were found in the same gradient fraction, $C_{1}$; however, in the secondary gradient (lower graph), ATP and 5-HT did not copurify. The highest concentration of ATP was found in fraction $\mathrm{B}_{2}$, while that of 5-HT was found in fraction $\mathrm{C}_{2}$. Fraction $\mathrm{C}_{2}$ contains most of the parafollicular cell granules identified morphologically (see Fig. 12) and by the demonstration of calcitonin immunoreactivity (see Fig. 12).

maffin granulcs, of nccessity, deal with a mixed population of granules, some of which contain epinephrine, while others contain norepinephrine.

At the subcellular level, the possible existence of different types of parafollicular cell granule was investigated using electron microscopic immunocytochemistry. Although all granules showed calcitonin immunoreactivity, 5-HT immunoreactivity colocalized with calcitonin immunoreactivity only in about half. No other organelles were found that contained immunoreactive 5-HT. $45 \mathrm{kDa}$ SBP immunoreactivity was found in a similar proportion of the granules to that of 5-HT and colocalized with 5-HT. There are 2 possible explanations for these observations. There may really be multiple types of parafollicular cell granule, one of which contains all 3 of the markers studied, while the others contain only calcitonin (or calcitonin in combination with 

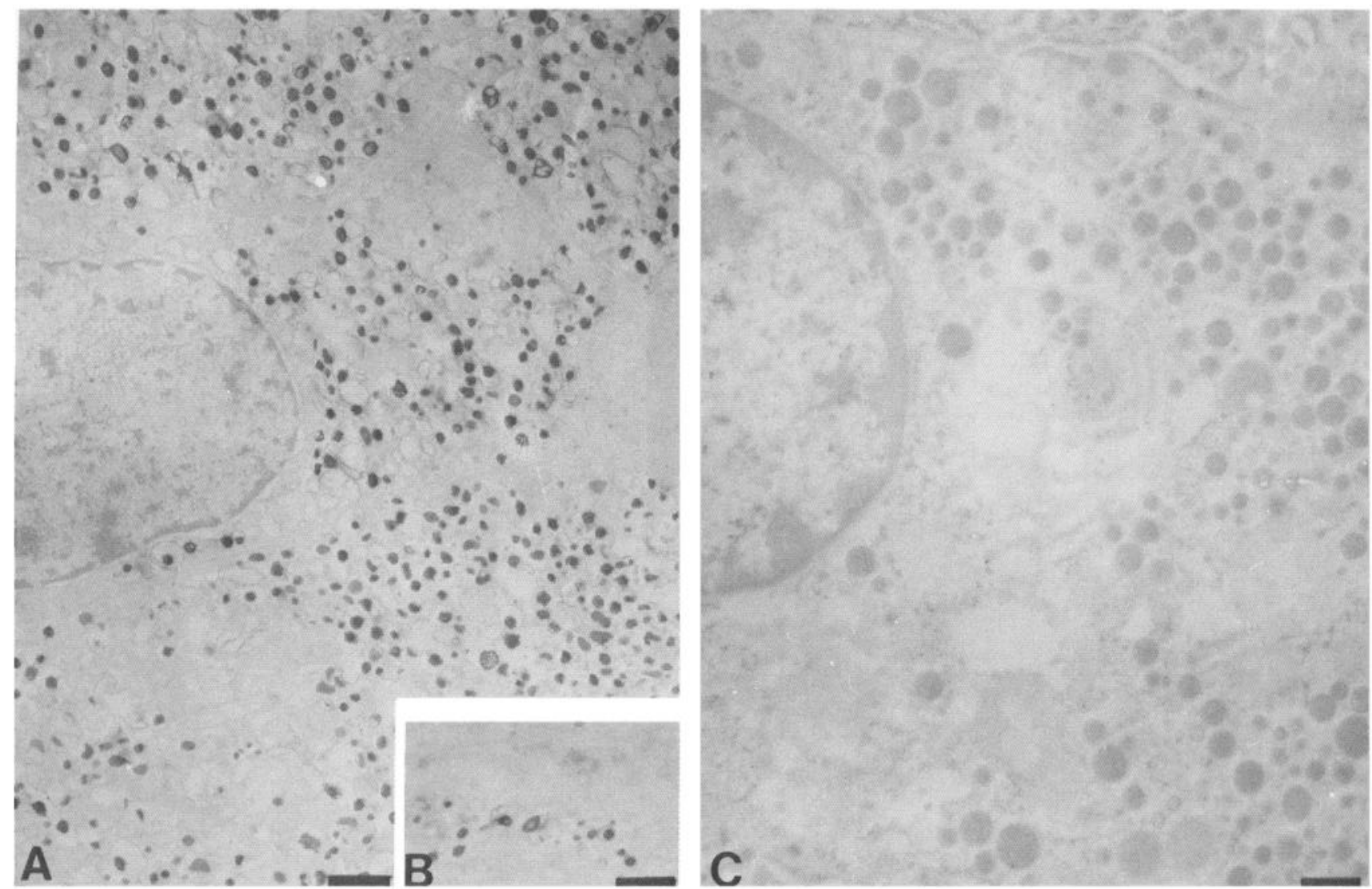

Figure 15. Electron micrographs showing the uranaffin reaction in the murine adrenal medulla $(A)$, intravascular platelets $(B$; inset), and in a sheep parafollicular cell $(C)$. The cores of the adrenal chromaffin granules are highly reactive $(A)$, as are the 5-HT storage granules of platelets $(B)$; however, no uranaffin reactivity can be detected in the secretory granules of the parafollicular cell $(C)$. Scale markers, $0.5 \mu \mathrm{M}$.

only one of the other 2 antigens). Alternatively, some granules may contain less $5-\mathrm{HT}$ and $45 \mathrm{kDa}$ SBP than is required to reach threshold for the immunocytochemical detection of these antigens. This possibility is supported by the observation that the number of granules displaying 5-HT immunoreactivity could be increased by using a different antiserum. Furthermore, every parafollicular cell granule in vivo has been found to take up newly synthesized ${ }^{3} \mathrm{H}-5-\mathrm{HT}$ (Nunez and Gershon, 1972). Moreover, different types of granule cannot be differentiated by their morphology or calcitonin content, and stimuli that release calcitonin from parafollicular cells release 5-HT as well (Gershon et al., 1978; Nunez and Gershon, 1983). It thus seems probable that there is only one type of parafollicular cell granule; however, individual granules probably do differ in their $5-\mathrm{HT}$ and $45 \mathrm{kDa}$ SBP content.

The sheep thyroid contains both 45 and $56 \mathrm{kDa}$ SBP; nevertheless, we found only the $45 \mathrm{kDa}$ SBP in parafollicular cells by immunocytochemistry and by immunoblot analysis of isolated parafollicular cells and parafollicular cell granules. The brain and the gut have been found to contain both 45 and $56 \mathrm{kDa}$ SBP, and both appear to be present in the serotonergic neurons of these organs (Gershon et al., 1983; Liu et al., 1985). On the other hand, there is evidence that $45 \mathrm{kDa} \mathrm{SBP}$, and not $56 \mathrm{kDa}$ $\mathrm{SBP}$, is present in serotonergic axon terminals. When the brain is perfused with ${ }^{3} \mathrm{H}-5-\mathrm{HT}$, or the enteric nervous system is incubated with ${ }^{3} \mathrm{H}-5-\mathrm{HT}$, a complex of ${ }^{3} \mathrm{H}-5$ - $\mathrm{HT}$ preferentially bound to $45 \mathrm{kDa}$ SBP can be isolated from the treated tissue (Gershon et al., 1983). ${ }^{3} \mathrm{H}-5$-HT is taken up mainly by sero- tonergic terminals in the perfused brain (Chan-Palay, 1975; Calas et al., 1976; Descarries et al., 1982) or incubated gut (Gershon and Altman, 1971; Dreyfus et al., 1977; Gershon et al., 1983). Within these terminals it enters synaptic vesicles and can be released from the terminals (in a $\mathrm{Ca}^{+2}$-dependent manner) by electrical stimulation (Chase et al., 1968; Jonakait et al., 1979; Gershon and Tamir, 1981). The fact that the form of SBP found to bind ${ }^{3} \mathrm{H}-5-\mathrm{HT}$ in situ is the $45 \mathrm{kDa}$ SBP suggests, therefore, that $45 \mathrm{kDa}$ SBP is the dominant species in synaptic endings and vesicles (Gershon et al., 1983). The observation that thyroid parafollicular cell granules also contain the $45 \mathrm{kDa}$ SBP is thus consistent with the idea that $45 \mathrm{kDa}$ SBP is a component of 5 -HT storage organelles of the neural type.

The demonstration of $56 \mathrm{kDa}$ SBP in unmyelinated thyroid nerve fibers raises the unanswered question of what kind of nerves these are. They were found not to be noradrenergic and did not stain in preparations treated with antibodies to 5-HT. Since they were not noradrenergic, the axons were not sympathetic and so were probably afferent fibers. Nevertheless, serotonergic nerves have been reported to be present in the thyroid gland of the dog (Takagi et al., 1986). Conceivably, thyroid serotonergic axons, if any exist, like those of the brain and gut, are difficult to demonstrate unless the concentration of 5-HT in the tissue is raised.

Parafollicular cell granules were further characterized by analyzing subcellular fractions. A number of investigators have successfully isolated amine storage organelles, including chromaffin granules, on Percoll gradients (Carty et al., 1980, 1981; 
Hutton and Peshavaria, 1982). For this reason we used Percoll as a density-gradient medium for an investigation of the ability of parafollicular cell granules to accumulate ${ }^{3} \mathrm{H}-5-\mathrm{HT}$. When the crude granular fraction derived from thyroid homogenates was layered on Percoll and centrifuged, a dense fraction was obtained in which 5-HT and calcitonin immunoreactivity were both concentrated. This fraction was found, upon electron microscopic examination, to be highly enriched in parafollicular cell granules. When loaded with ${ }^{3} \mathrm{H}-5-\mathrm{HT}$ by incubating the crude granular fraction, these granules were found to retain enough radioactivity, despite passage through the Percoll gradient, to be demonstrable by electron microscopic radioautography. The Percoll gradient, however, did not fully separate parafollicular cell granules from lysosomes. Nevertheless, the contamination of the vesicular fraction by lysosomes did not interfere with the demonstration of specific ${ }^{3} \mathrm{H}-5-\mathrm{HT}$ uptake and retention by isolated granules. Since radioautographs revealed that only the secretory granules, and not lysosomes, were labeled when the crude granular fraction was incubated with ${ }^{3} \mathrm{H}-5-\mathrm{HT}$, the recovery of ${ }^{3} \mathrm{H}-5-\mathrm{HT}$ in the vesicular fraction of the Percoll gradient could be attributed to the sedimentation of labeled granules. The uptake of ${ }^{3} \mathrm{H}-5-\mathrm{HT}$ by parafollicular cell granules, was inhibited by cold and even more by reserpine. This observation indicates that the phenomenon is similar to the granular uptake of ${ }^{3} \mathrm{H}-5-\mathrm{HT}$ in intact cells, which also is reserpine-sensitive (Nunez and Gershon, 1972; Gershon and Nunez, 1973).

Metrizamide gradients were used to improve the yield of isolated granules and their separation from lysosomes. Two gradients were used. The first, in which components were found by electron microscopy to distribute according to size, separated parafollicular cell granules from mitochondria and lysosomes and showed copurification of 5-HT and $45 \mathrm{kDa}$ SBP. The second gradicnt, in which components distributed according to density, enriched the parafollicular cell granules further. This combined 2-step, size then density, separation resulted in a fraction in which 5-HT was concentrated and which contained morphologically recognizable parafollicular cell granules that represented $62 \%$ of the particulate volume of the fraction. It was concluded that this fraction could be used to study the contents of parafollicular cell granules and, in particular, ATP.

A number of biogenic amine storage granules have been shown to contain high concentrations of nucleotides, especially ATP. High nucleotide content of granules in situ can be revealed by the uranaffin cytochemical reaction, in which uranium salts precipitate over the tightly packed phosphate groups of granular nucleotides (Richards and Da Prada, 1977); moreover, ATP content can also be measured in isolated granules by the luciferin-luciferase assay (Rasmussen and Nielsen, 1968; Carty et al., 1980). These methods have revealed a high concentration of ATP in chromaffin granules $(800 \mathrm{nmol}$ ATP/mg protein: Carty et al., 1980; Johnson et al., 1982), platelet granules (243.4 nmol ATP/mg protein: Carty et al., 1981), and the synaptic vesicles from the vas deferens and the superior cervical ganglion (Lagercrantz, 1976). Winkler and Westhead (1980) have suggested that intragranular ATP may facilitate the formation of macromolecular complexes with biogenic amines, thercby reducing the intravesicular osmotic pressure from what it would be if the amines were free in solution. ATP has also been proposed to act as a cotransmitter or neuromodulator upon its release with a biogenic amine (Meldrum and Burnstock, 1983; Sneddon and Westfall, 1984). An ecto-kinase activity may be involved in still other functions of ATP released along with a transmitter from nerve endings (Ehrlich et al., 1986). The present investigation, however, indicates that there is little or no ATP in parafollicular cell granules. The evidence includes the following: (1) 5-HT and ATP do not copurify when the parafollicular granules are separated from other organelles by density in a metrizamide gradient; (2) ATP is present only in minor amounts $(0.17 \pm 0.01 \mathrm{nmol} / \mathrm{mg}$ protein; 3 orders of magnitude less than in comparable fractions of adrenal medullary or platelet granules) in the most highly enriched granule fraction; (3) the ratio of 5-HT/ATP is 26:1 in this fraction, rather than the 4 catecholamines:1 ATP found in similarly purified adrenal chromaffin cell granules (Hillarp, 1958; Winkler, 1976) or the 1 5-HT:2 ATP found in platelet granules (Carty et al., 1981); (4) the uranaffin reaction failed to produce dense precipitates over parafollicular cell granules but did yield such precipitates over chromaffin and platelet granules, which served as positive controls. The report that the uranaffin reaction fails to demonstrate nucleotides in the vesicles of the supraependymal axons of the brain, which are known to be serotonergic (Richards, 1983), suggests that serotonergic synaptic vesicles are likely to be similar to parafollicular cell granules in containing relatively little or no ATP. Perhaps SBP serves the function of facilitating the formation of macromolecular complexes with 5-HT that may be served by ATP in catecholaminergic or platelet vesicles. Such 5-HT-SBP complexes might limit the osmotic pressure within vesicles and contribute to granular uptake of 5-HT by trapping the amine within granules. The observation that reserpine inhibits both the binding of ${ }^{3} \mathrm{H}-5-\mathrm{HT}$ by SBP and the accumulation of ${ }^{3} \mathrm{H}-5-\mathrm{HT}$ in isolated granules is consistent with the possibility that granular uptake and retention are facilitated by the binding of 5-HT by SBP.

\section{References}

Atack, C. V., L. E. Ericson, and A. Melander (1972) Intracellular distribution of amines and calcitonin in the sheep thyroid gland. J. Ultrastruct. Res. 41: 484-498.

Barasch, J. M., H. Mackey, H. Tamir, E. A. Nunez, and M. D. Gershon (1987) Induction of a neural phenotype in a serotonergic endocrine cell derived from the neural crest. J. Neurosci. 7: 2874-2883.

Bernd, P., M. D. Gershon, E. A. Nunez, and H. Tamir (1979) Localization of a highly specific neuronal protein, serotonin binding protein, in thyroid parafollicular cells. Anat. Rec. 193: 257-268.

Bernd, P., M. D. Gershon, E. A. Nunez, and H. Tamir (1981) Separation of dissociated thyroid follicular and parafollicular cells: Association of serotonin binding protein. J. Cell Biol. 88: 499-508.

Berod, A., B. K. Hartman, and J. F. Pujol (1981) Importance of fixation in immunohistochemistry: Use of formaldehyde solutions at variable $\mathrm{pH}$ for the localization of tyrosine hydroxylase. J. Histochem. Cytochem. 29: 844-850.

Bussolati, G., and A. G. E. Pearse (1967) Immunofluorescent localization of calcitonin in the C-cells of pig and dog thyroids. J. Endocrinol. 37: 205-209.

Calas, A., M. J. Bensson, G. Gaughy, G. Alonso, J. Glowinski, and A. Cheramy (1976) Radioautographic study of in vivo incorporation of ${ }^{3} \mathrm{H}$-monoamines in cat caudate nucleus: Identification of serotonergic fibers. Brain Res. 118: 1-13.

Carty, S., R. G. Johnson, and A. Scarpa (1980) The isolation of intact adrenal chromaffin granules using isotonic percoll density gradients. Anal. Biochem. 106: 438-445.

Carty, S., R. G. Johnson, and A. Scarpa (1981) Serotonin transport in isolated platelet granules. J. Biol. Chem. 256: 11244-11250.

Cerletti, P., M. A. Giovenco, M. G. Giordano, S. Giovenco, and R. Strom (1967) Succinic dehydrogenase. 1. Role of phospholipids. Biochim. Biophys. Acta 146: 380-396.

Chan-Palay, V. (1975) Fine structure of labelled axons in the cerebellar cortex and nuclei of rodents and primates after intraventricular infusions with tritiated serotonin. J. Anat. Embryol. 148: 235-265. 
Chase, T. N., G. R. Breese, D. O. Carpenter, S. M. Schanberg, and I. J. Kopin (1968) Stimulation induced release of serotonin. Adv. Pharmacol. 6: 351-364.

Coupland, R. E., and D. Hopwood (1966) Mechanism of histochemical reaction differentiating between adrenaline and noradrenaline storing cells in the electron microscope. Nature 209: 590-591.

Dahlstrom, A., and K. Fuxe (1964) Evidence for the existence of monoamine containing neurons in the central nervous system. I. Demonstration of monoamines in cell bodies of brain stem neurons. Acta Physiol. Scand. (Suppl.) 232: 1-55.

DeLorenzo, R. J., and S. D. Freedman (1978) Calcium dependent neurotransmitter release and protein phosphorylation in synaptic vesicles. Biochem. Biophys. Res. Commun. 80: 182-192.

Descarries, L., K. C. Watkins, S. Garcia, and A. Beaudet (1982) The serotonin in the nucleus raphe dorsalis of adult rat: A light and electron microscope radioautographic study. J. Comp. Neurol. 207: 239-354.

Dreyfus, C. F., D. L. Sherman, and M. D. Gershon (1977) Uptake of serotonin by intrinsic neurons of the myenteric plexus grown in organotypic tissue culture. Brain Res. 128: 109-123.

Ehrlich, Y. H., T. B. Davis, E. Bock, G. Kornecki, and R. H. Lenox (1986) Ectoprotein kinase activity on the external surface of neural cells. Nature 320:67-69.

Elias, H., A. Hennig, and D. E. Schwartz (1971) Stereology: Application to biomedical research. Physiol. Rev. 51: 158-200.

Ericson, L. E. (1970) Subcellular localization of 5-hydroxytryptamine in the parafollicular cells of the mouse thyroid gland. An autoradiographic study. J. Ultrastruct. Res. 31: 162-177.

Falck, B., and C. Owman. (1968) 5-Hydroxytryptamine and related amines in endocrine cell systems. Adv. Pharmacol. 6A: 211-231.

Fishman, W. H., S. S. Goldman, and R. DeLellis (1948) Application of an improved glucuronidase assay method to the study of human blood $\beta$-glucuronidase. J. Biol. Chem. 173: 449.

Fujita, H. (1975) Fine structure of the thyroid gland. Int. Rev. Cytol. 40: $197-280$.

Fujita, T. (1977) Concept of paraneurons. Arch. Histol. Jpn. 40(Suppl.): $1-12$.

Fujita, T., S. Kobayashi, and T. Uchida (1984) Secretory aspect of neurons and paraneurons. Biomed. Res. 5(Suppl.): 1-8.

Furness, J. B., J. W. Health, and M. Costa (1978) Aqueous aldehyde (Faglu) methods for the fluorescence histochemical localization of catecholamines and for ultrastructural studies of central nervous tissue. Histochemistry 57: 285-295.

Fuxe, K., and G. Jonsson (1967) A modification of the histochemical fluorescence method for the improved localization of 5-hydroxytryptamine. Histochemie 11: 161-166.

Garattini, S., and L. Valzelli (1965) Serotonin, pp. 53-81, Elsevier, New York.

Gershon, M. D. (1977) Biochemistry and physiology of serotonergic transmission. In Handbook of Physiology, J. Brookhart and V. Mountcastle, eds., pp. 573-624, American Physiology Society/Waverly, Baltimore.

Gershon, M. D. (1981) The enteric nervous system. Annu. Rev. Neurosci. 4: 227-272.

Gershon, M. D., and R. F. Altman (1971) An analysis of the uptake of 5-hydroxytryptamine by the myenteric plexus of the small intestine of the guinea pig. J. Pharmacol. Exp. Ther. 179: 29-41.

Gershon, M. D., and E. A. Nunez (1970) Histochemical and radioautographic studies of serotonin and parafollicular cells in the thyroid glanld of the prehibernating bat. Endocrinology 86: 160-166.

Gershon, M. D., and E. A. Nunez (1973) Subcellular storage organelles for 5-hydroxytryptamine in parafollicular cells of the thyroid gland. J. Cell Biol. 56: 676-689.

Gershon, M. D., and E. A. Nunez (1976) Uptake of biogenic amines by thyroid glands. Mol. Cell Endocrinol. 5: 169-180.

Gershon, M. D., and L. L. Ross (1966a) Radioisotopic studies of the binding, exchange, and distribution of 5-hydroxytryptamine synthesized from its radioactive precursor. J. Physiol. (Lond.) 186: 451476.

Gershon, M. D., and L. L. Ross (1966b) Location of sites of 5-hydroxytryptamine storage and metabolism by radioautography. $\mathrm{J}$. Physiol. (!_ond.) 186: 477-492.

Gershon, M. D., and H. Tamir (1981) Release of endogenous 5-hydroxytryptamine from resting and stimulated enteric neurons. Neuroscience 6: 2277-2286.

Gershon, M. D., and H. Tamir (1984) Serotonectin and the family of proteins that bind serotonin. Biochem. Pharmacol. 33: 3115-3118. Gershon, M. D., D. Kanarek, and E. A. Nunez (1978) Calcium-induced release of 5-hydroxytryptamine from thyroid lobes in vitro and accompanying ultrastructural changes in parafollicular and follicular cclls. Endocrinology 103: 1128-1142.

Gershon, M. D., K. P. Liu, S. E. Karpiak, and H. Tamir (1983) Storage of serotonin in vivo as a complex with serotonin-binding protein in central and peripheral serotonergic neurons. J. Neurosci. 3: 19011911.

Goodrich, J. T., P. Bernd, D. Sherman, and M. D. Gershon (1980) Phylogeny of enteric serotonergic neurons. J. Comp. Neurol. 190: 1528.

Hillarp, N. A. (1958) Adenosinephosphates and inorganic phosphate in the adrenaline and noradrenaline containing granules of the adrenal medulla. Acta Physiol. Scand. 43: 82-96.

Holz, R. (1986) The role of osmotic forces in exocytosis from adrenal chromaffin cells. Annu. Rev. Physiol. 48: 175-189.

Holzwarth, M. A., and C. Sawetawan (1985) Postnatal development of serotonin in adrenal medullary cells. Brain Res. Bull. 14: 15-23.

Hutton, J. C., and M. Peshavaria (1982) Proton translocating $\mathrm{Mg}^{+2}$ dependent ATPase activity in insulin-secretory granules. Biochem. J. 204: $161-170$.

Ingbar, S. (1985) The thyroid gland. In Williams' Textbook of Endocrinology, 7th ed., J. D. Wilson and D. W. Forster, eds., pp. 682815, Saunders, Philadelphia, PA.

Jaim-Etcheverry, G., and L. M. Zeiher (1968) Cytochemical localization of monoamine stores in sheep thyroid gland at the electron microscope level. Experientia 24: 593-596.

Johnson, R. G., and A. Scarpa (1979) Proton motive force and catecholamine transport in isolated chromaffin granules. J. Biol. Chem. 254: $3750-3760$.

Johnson, R. G., S. Carty, and A. Scarpa (1982) A model of biogenic amine accumulation into chromaffin granules and ghosts based on coupling to the electrochemical proton gradient. Fed. Proc. 41:27462754 .

Jonakait, J. M., H. Tamir, M. M. Rapport, and M. D. Gcrshon (1977) Detection of a soluble serotonin binding protein in mammalian myenteric plexus and other peripheral sites of serotonin storage. J. Neurochem. 28: 277-284.

Jonakait, J. M., H. Tamir, A. R. Gintzler, and M. D. Gershon (1979) Release of serotonin and its binding protein by enteric neurons. Brain Res. 174: 55-69.

Kalina, M., and A. G. E. Pearse (1971) Ultrastructural localization of calcitonin in C cells of dog thyroid: An immunocytochemical study. Histochemie 26: 1-8.

Kameda, Y., H. Oyama, M. Endoh, and M. Horino (1982) Somatostatin immunoreactive c cells in thyroid glands from various mammalian species. Anat. Rec. 204: 161-170.

Lagercrantz, H. (1976) On the composition and function of large dense cored vesicles in sympathetic nerves. Neuroscience 1: 81-92.

Le Douarin, N. (1982) The Neural Crest, Cambridge University Press. London.

Liu, K. P., M. D. Gershon, and H. Tamir (1985) Identification, purification and characterization of serotonin binding protein from rat brain. J. Neurochem. 44: 1289-1295.

Machado, C. R. S. (1976) Monoamines in the C cells of the thyroid gland of callithricid primates. Histochemistry 48: 187-190.

Meldrum, L. A., and G. Burnstock (1983) Evidence that ATP acts as a co-transmitter with noradrenaline in sympathetic nerves supplying the guinea-pig vas deferens. Eur. J. Pharmacol. 92: 161-163.

Nunez, E. A., and M. D. Gershon (1972) Synthesis and storage of serotonin by parafollicular (C) cells of the thyroid gland of active, prehibernating and hibernating bats. 1972. Endocrinology 90: 10081024.

Nunez, E. A., and M. D. Gershon (1983) Thyrotropin-induced thyroidal release of 5-hydroxytryptamine and accompanying ultrastructural changes in parafollicular cells. Endocrinology 113: 309-317.

Payette, R. F., M. D. Gershon, and E. A. Nunez (1986) Colocalization of luteinizing hormone and serotonin in secretory granules of mammalian gonadotrophs. Anat. Rec. 215: 51-58.

Pearse, A. G. E. (1966) Common cytochemical properties of cells producing polypeptide hormones, with particular reference to calcitonin and the thyroid C cells. Vet. Rec. 79: 587-590.

Phillips, J. H. (1982) Dynamic aspects of chromaffin granule structure. Neuroscience 7: 1595-1609. 
Polak, J. M., A. G. E. Pearse, C. Le Lièvre, J. Fontaine, and N. M. Le Douarin (1974) Immunocytochemical confirmation of the neural crest origin of avian calcitonin-producing cells. Histochem. 40:209214.

Rasmussen, H., and R. Niclsen (1968) An improved analysis of adenosine triphosphate by the luciferase method. Acta Chem. Scand. 22: $1745-1756$

Reinhard, J. F., M. A. Moskowitz, A. F. Sved, and J. D. Fernstrom (1980) A simple, sensitive and reliable assay for serotonin and 5-HIAA in brain tissue using liquid chromatography with electrochemical detection. Life Sci. 27: 905-911.

Richards, G. (1983) Ultrastructural visualization of biogenic monoamines. In Handbook of Chemical Neuroanatomy, Vol. 1: Methods in Chemiocal Neuroanatomy, A Björklund and T. Hölfelt, ed., pp. 122-146, Elsevier, New York.

Richards, J. G., and M. Da Prada (1977) Uranaffin reaction: A new cytochemical technique for the localization of adenine nucleotides in organelles storing biogenic amines. J. Histochem. Cytochem. 25: 13221336.

Salpeter, M. M., L. Bachmann, and E. E. Salpeter (1969) Resolution in electron microscopic radioautography. J. Cell Biol. 41: 1-20.

Slotkin, T., F. Seidler, W. Whitmore, C. Lau, M. Salvaggio, and D. Kirksey (1978) Rat brain synaptic vesicles: Uptake specificities of $\left({ }^{3} \mathrm{H}\right)$ norepinephrine and $\left({ }^{3} \mathrm{H}\right)$ serotonin in preparations from whole brain and brain regions. J. Neurochem. 31: 961-968.

Sneddon, P., and D. P. Westfall (1984) Pharmacological evidence that adenosine triphosphate and noradrenaline are co-transmitters in the guinea pig vas deferens. J. Physiol. (Lond.) 347: 561-580.

Takagi, I., K. Yamada, N. Karasawa, and I. Nagatsu (1986) Peptide and amine immunoreactive parafollicular cells in dog thyroid gland. Biogenic Amines 3: 181-192.

Tamir, H., and M. D. Gershon (1979) Storage of serotonin and serotonin binding protein in synaptic vesicles. J. Neurochem. 33: 35-44.

Tamir, H., A. Klein, and M. M. Rapport (1976) Serotonin binding protein: Enhancement of binding by $\mathrm{Fe}^{+2}$ and inhibition of binding by drugs. J. Neurochem. 26: 871-878.
Tamir, H., R. Bebirian, F. Muller, and D. Casper (1980) Differences between intracellular platelet and brain proteins that bind serotonin. J. Neurochem. 35: 1033-1044.

Tamir, H., S.C. Hsiung, M. D. Gershon, Y. L. Huang, and K. P. Liu (1986) Preparation and characterization of affinity purified antibodies to serotonin binding protein. Trans. Am. Soc. Neurochem. 17: 296.

Thureson-Klein, $\AA$. (1983) Exocytosis from large and small dense cored vesicles in noradrenergic nerve terminals. Neuroscience 10 : 245-252.

Udenfriend, S., S. Stein, P. Bohlen, W. Dairman, W. Leimgruber, and M. Weigele (1972) Applications of fluorescamine, a new reagent for assay of amino acids, peptides, proteins and other primary amines in the picomole range. Science 178: 871-873.

Van Noorden, S., J. M. Polak, and A. G. E. Pearse (1977) Single cellular origin of somatastatin and calcitonin in the rat thyroid gland. Histochemistry 53: 243-247.

Verhofstad, A. A. J., and G. Jonsson (1983) Immunohistochemical and neurochemical evidence of serotonin in the adrenal medulla of the rat. Neuroscience $10: 1443-1453$.

Williams, A. (1969) The assessment of electron microscopic autoradiographs. Adv. Opt. Elect. Microsc. 3: 219-272

Winkler, H. (1976) Composition of adrenal chromaffin granules: An assessment of controversial results. Neuroscience 1:65-80.

Winkler, H., and E. Westhead (1980) The molecular organization of adrenal chromaffin granules. Neuroscience 5: 1803-1823.

Zabel, M. (1983) Ultrastructural localizations of calcitonin in control and stimulated thyroid $C$ cells of the rat using protein A-gold immunocytochemical technique. Histochemistry 77: 269-273.

Zabel, M. (1984) Ultrastructural localization of calcitonin, somatostatin and serotonin in parafollicular cells of rat thyroid. Histochem. J. 16: 1265-1272.

Ziegler, D. M., and K. A. Doeg (1962) Studies on the electron transportsystem. XLIII. The isolation of a succinic-coenzyme $Q$ reductase from beef heart mitochondria. Arch. Biochem. Biophys. 97: 41-50. 